\title{
Economic Booms and Risky Sexual Behavior: Evidence from Zambian Copper Mining Cities*
}

\author{
Nicholas Wilson \\ Department of Economics, Williams College, Williamstown, MA 01267, United States ${ }^{\dagger}$
}

First draft: July 2010

Current draft: October 2011

\begin{abstract}
Existing studies suggest that individual and household level economic shocks affect the demand for and supply of risky sex. However, little evidence exists on the effects of an aggregate shock on equilibrium risky sexual behavior. This paper examines the effects of the early twenty-first century copper boom on risky sexual behavior in Zambian copper mining cities. The results indicate that the copper boom substantially reduced rates of transactional sex and multiple partnerships in copper mining cities. These effects were partly concentrated among young adults and copper boom induced in-migration to mining cities appears to have contributed to these reductions.
\end{abstract}

JEL classification: I18, J10, O12, O40

Keywords: commodity shocks, copper mining, economic growth, HIV/AIDS, Zambia

*I would like to thank Andrew Foster, Bill Gentry, Jeanne Lafortune, Sara Lalumia, Peter Pedroni, Jonathan Robinson, Michael Rolleigh, Manisha Shah, Stephen Sheppard, Lara Shore-Sheppard, Anand Swamy, and Tara Watson, as well as seminar participants at IZA 3rd Annual Meeting on the Economics of Risky Behavior 2011, NEUDC 2010, PAA 2011, Wesleyan University, and Williams College, for many helpful comments. In addition, this research would not be possible without the assistance of Alfred Phiri at the Zambia Ministry of Mines and Minerals Development. Zhaoning Wang, Madeleine Watson, and Wentao Xiong provided superb research assistance. All errors are my own. The findings, interpretations, and conclusions expressed in this paper are those of the author and do not necessarily represent the views of the aforementioned individuals or their employers.

†Tel.: +1 4135974868 Fax: +1 4135974045 E-mail: nlw3@williams.edu 


\section{Introduction}

Copper mining is one of the largest economic activities in Zambia, comprising close to 10 percent of GDP (USAID 2006). During the global economic expansion of the mid-2000s, demand for copper rose dramatically. As a result, the world copper price increased by over 400 percent between 2003 and 2008. In response to the large increase in the world copper price, copper production in Zambian copper mining cities boomed. Between 2003 and 2008, copper output in Zambia increased by 70 percent, employment in copper mining increased by 180 percent, and real GDP per capita grew by 76 percent (between 2003 and 2007).

This paper examines the effect of the copper boom on risky sexual behavior in Zambia, a country in which roughly one in six adults is HIV positive. In doing so, it provides some of the first causal evidence on the effect of economic booms on risky sexual behavior and in turn informs a growing policy debate: the effect of economic growth on the HIV/AIDS pandemic. Some in this debate (e.g., Fenton 2004) argue that poverty reduction is an important component in the fight against HIV/AIDS. Others emphasize that there is a positive gradient in the relationship between wealth and HIV prevalence, both within countries (Mishra et al 2007) and across countries in Sub-Saharan Africa (Parkhurst 2010).

Although there is little empirical evidence on the causal effects of economic growth or economic booms on risky sexual behavior and the HIV/AIDS pandemic, several studies have examined the effect of individual and household level economic shocks on sexual behavior. Dinkelman et al (2007) find in a panel of young adults in Cape Town, South Africa that negative household level economic shocks (e.g., death or job loss) are associated with an increased likelihood of young women in these households having multiple sexual partners. Robinson and Yeh (2010) find that among a sample of 192 commercial sex workers in Busia District, Kenya individual and household level negative health shocks increase willingness to supply particularly risky transactional sex. Other studies which examine compensating differentials in sex markets, such as Gertler et al (2005), find that unprotected sex is associated with a price premium in the transactional sex market, possibly suggesting that rising incomes among consumers of transactional sex may lead to increased risky sexual behavior. Dupas and Robinson (2011) is one of the few microeconomic analyses of the effects of a large (albeit relatively short-lived) country-wide shock on the supply of risky sexual behavior. In that study, female transactional sex workers engaged in higher risk sex during and after a very disruptive nationwide political crisis that substantially reduced incomes. 
As partly indicated by these studies, it is unclear whether economic growth will help alleviate the HIV/AIDS pandemic by reducing risky sexual behavior or exacerbate it by increasing risky sexual behavior. Rising wages and incomes, as well as associated socioeconomic and cultural changes, affect both the supply of sex and demand for sex. Increased employment opportunities for women outside of the transactional sex market should lead to a decrease in the supply of risky sex. Conversely, rising incomes among men may lead to an increase in demand for sex. Income and substitution effects from increased labor demand affect fertility decisions and marriage, which in turn affect sexual behavior. Other literature, such as Lurie et al (2003) and Oster (2009a), discusses the role of migration in the spread of HIV/AIDS, and economic booms and growth affect migration. In addition, Oster (2009b) argues that higher incomes may increase the behavioral response to increased HIV risk. In this model, individuals with higher incomes face a higher marginal cost of risky behavior because of the greater forgone utility in expectation from increased risk of death. Although this suggests that economic growth or large economic shocks might reduce risky sexual behavior, the causal evidence on this issue remains scant.

I use the large increase in Zambian copper output associated with the world price shock as a quasi-experiment to estimate the effects of copper production on risky sexual activity in Zambian copper mining cities. Because of substantial variation across mining cities in the production response to the world price shock, I focus on estimating the effects of variation in the intensity of copper production during the boom instead of implementing a simple difference-in-differences specification. Data on sexual behavior come from repeated nationally representative cross-sectional household surveys conducted at multiple points before and during the boom. Detailed geographic information on the location of survey respondents and copper mines combined with monthly minelevel copper output data allow me to isolate plausibly exogenous spatial and temporal variation in the intensity of the copper boom from time-invariant spatial heterogeneity and time-specific shocks.

To the best of my knowledge, these are the first estimates of the effects of a large and sustained shock to aggregate production on equilibrium risky sexual behavior. Several key findings emerge from this analysis. First, the copper boom caused relatively large reductions in transactional sex and multiple partnerships, arguably the two riskiest activities reliably captured in sexual behavior data, as well as a reduction in pregnancy rates for younger women. Second, these effects appear to have been concentrated within the urban areas surrounding the mines. Third, the spatial pattern of changes in consumer durable ownership and migration status are consistent with the interpretation that the effects of the copper shock were very localized. Fourth, younger individuals and males, the 
individuals who generally report engaging in the riskiest sexual behaviors, tended to demonstrate the greatest reductions in risky behavior. Fifth, copper boom induced in-migration appears to have contributed to these effects, meaning that the reduction in risky behavior in mining cities likely reflects in part a compositional change generated by the copper boom in the population residing in mining cities.

These results offer new insights for understanding the effects of economic growth or economic booms on risky sexual behavior and the HIV/AIDS pandemic in Sub-Saharan Africa. Existing studies of the relationship between economic growth and HIV/AIDS focus on the effect of HIV/AIDS on economic growth (Young 2005) or its determinants (Fortson 2009, Fortson 2010, Juhn et al 2009). In the current study setting, I find that a large and sustained positive shock to aggregate production appears to have reduced particularly risky sexual behaviors where the intensity of the shock was the greatest. This suggests that the supply-side effects of rising incomes and economic opportunities for women outside of sexual activity dominate demand-side effects, if any, among men of rising incomes and increased willingness-to-pay for sex. ${ }^{1}$ In some sense, this may not be particularly surprising. The labor supply decisions of women at risk of entering the transactional sex market are probably quite responsive to increases in outside opportunities; transactional sex likely is a last resort. In contrast, many men, both low income and higher income, report engaging in transactional sex.

It is reasonable to believe that the effects of the copper boom on risky sexual behavior in the Zambian copper mining cities may parallel the effects of more balanced economic growth on economy-wide risky sexual behavior in other settings. The Zambian copper mines are located in relatively large cities with gender ratios close to one. ${ }^{2}$ Moreover, the results of the empirical analysis indicate that the boom affected average behavior in the mining cities (and the behavior of women),

\footnotetext{
${ }^{1}$ The finding in Robinson and Yeh (2010) that commercial sex workers increase their supply of particularly risky sex in response to negative individual- and household-level shocks is consistent with this interpretation. Similarly, Kohler and Thornton (2010) find that women receiving a conditional cash transfer (CCT) reduce their sexual activity in the week following the transfer. Kohler and Thornton (2010) also find that men receiving the CCT increase their sexual activity in the week following the transfer. These studies provide evidence on the effect of small shocks or small cash transfers on sexual activity among individual persons. One could also interpret these studies as providing evidence on the supply of sexual activity and the demand for sexual activity. In contrast, I provide some of the first causal evidence on the equilibrium effects of a large and sustained economic shock on sexual behavior in a long-term nationally-representative study.

${ }^{2}$ Data from the 2000 Census indicate that the ratio of males to females in the copper mining region (i.e., Copperbelt Province, whose population resides primarily in the copper mining cities) is 1.02.
} 
not just the behavior of (predominately male) miners.

However, several factors indicate that we should use caution in generalizing these results to other settings. Although mining booms appear to have been a substantial component of much of the recent economic growth in the region of the world most affected by the HIV/AIDS pandemic (Beny and Cook 2009), the Zambian mining cities do not appear to be the representative mining setting in Sub-Saharan Africa. A related caveat is that the relative responsiveness of the demand for and supply of risky behavior to an economic boom may depend on contextual factors such as pre-boom income levels, the degree of pre-boom income inequality, and how the direct benefits of the boom are distributed across women and men.

The paper proceeds as follows. Section 2 provides the institutional context for copper mining in Zambia and describes the copper boom. Section 3 outlines a conceptual framework for interpreting the empirical results. Section 4 discusses the data on sexual behavior, consumer durable ownership, and migration. Section 5 presents the empirical strategy. Section 6 presents the results. Section 7 concludes.

\section{Copper Mining in Zambia and the Copper Boom}

Copper mining is one of the largest economic activities in Zambia. It comprises approximately 10 percent of GDP (USAID 2006) and more than 60 percent of exports (United Nations Statistics Division 2009). The majority of copper ore mined in Zambia is smelted locally before being exported to foreign markets (Fraser and Lungu 2007). Copper and copper ore are transported by truck and rail to the south through Lusaka and on to South Africa and to the northeast through Kasama and Mpika to Tanzania.

Large-scale mining constitutes 90 to 95 percent of copper mining in Zambia. ${ }^{3}$ During the period examined in this analysis, there were eleven large-scale mines located in nine mining cities in northern Zambia. Figure 1 shows the spatial distribution of the mines, as well as the main transportation networks in Zambia and several of the larger non-mining cities, and district level population density. Eight of the mining cities are clustered together in Copperbelt Province and the other mining city, Solwezi, is in an adjacent province, Northwestern Province. Without exception, each mine is located within 10 kilometers of the approximate centroid of the nearest city and in

\footnotetext{
${ }^{3}$ Personal communication with Alfred Phiri, Mining Economist, Zambia Ministry of Mines and Minerals Development.
} 
many cases the mine is located virtually in the center of the city. Eight of these cities are among the twenty largest urban areas in Zambia. The ninth mining city, Chambishi, has a population of roughly $15,000 .^{4}$

For much of the post-colonial era, the Zambian government owned the large-scale mines. Beginning around 2000, the government privatized copper mining and all of the large-scale mines were under the control of private ownership by the end of 2004 (Fraser and Lungu 2007). The new majority owners of the mines and the associated capital inputs are British, Canadian, Chinese, Indian, South African, and Swiss companies. The government of Zambia remains a minority shareholder in two of the copper mining operations in Zambia.

Copper mining is less labor intensive than agriculture in Zambia and represents a smaller share of employment than of GDP. According to the 2005 Labor Force Survey (LFS), the "mining and quarrying" industry employed 56,227 workers, or approximately one percent of individuals aged 15 years and older. However, in Copperbelt Province, where ten of the eleven aforementioned large-scale mines are located, 8.9 percent of employment is in mining and quarrying. Not only are ten of the eleven aforementioned large-scale mines located in Copperbelt Province, but eighty-two percent of employees in mining and quarrying reside in Copperbelt Province.

The LFS indicates that workers in the mining and quarrying industry are highly skilled and highly paid relative to other workers in Zambia. Forty-five percent of workers employed in mining and quarrying have completed between grade 10 and grade 12, four percent of workers have completed A level, and seventeen percent of workers have a degree. Only two industries in Zambia are more highly skilled: "finance, insurance, and real estate" (40,666 workers) and "electricity, gas, and water" (17,122 workers). Average earnings among mining and quarrying employees are approximately 986,000 kwacha (or roughly US\$200) per month, again behind only finance, insurance, and real estate (1.22 million kwacha) and electricity, gas, and water (1 million kwacha).

The LFS also shows that mining employees are predominately relatively older males who work full-time. Mining and quarrying has the greatest proportion of full-time workers of any industry and these employees work 56 hours a week on average. Ninety-three percent of mining and quarrying employees are male and the majority of females employed in mining and quarrying are part-time

\footnotetext{
${ }^{4}$ The high population densities and balanced gender ratios around the Zambian copper mines make this context different from many other mining settings. For example, Stuckler et al (2010) describe a setting where most of the population near mines are mine workers who reside in all-male hostels and many of the local female residents are sex workers who locate near the mines because of the large concentration of men.
} 
workers. At least at the onset of the copper boom, workers in the mining and quarrying industry were older than in any other industry. For example, 20 percent of workers were aged 40-44.

As shown in Figure 2, in early-to-mid-2003 the world copper price began to increase dramatically after twenty-five years of relative stability. ${ }^{5}$ By the time it reached its peak in April of 2008, it had risen by 428 percent. ${ }^{6}$ This increase was much larger than the two price shocks of the late-1980s and the mid-1990s, the largest of which was a 175 percent increase ending in February of 1989.

The large increase in the world copper price was an exogenous shock to Zambian copper production. Although copper is one of its largest economic activities and Zambia was the 8th largest producer of copper in the world in 2006, Zambia produces a small share of the world's copper supply. For example, Zambia produced nearly 515,000 metric tons of copper ore in 2006, which constituted 3.4 percent of the total world output of more than 15 million metric tons. In contrast, total copper output in Chile, the world's largest copper producer, equaled 5,361,000 metric tons in 2006 (International Copper Study Group 2010). ${ }^{7}$ The most recent copper cartel, the Intergovernmental Council of Copper Exporting Countries (CIPEC), was founded in 1967 (Panayotou 1979). Indeed Zambia was a founding member, but the cartel ended in 1988, consistent with the finding (Pindyck 1978) that copper cartelization yields only minor benefits to cartel members because of the responsiveness of secondary (i.e., scrap) copper supply.

In response to the copper price shock, copper production in Zambia boomed. In 2002, the year prior to the price shock, annual copper production was approximately 335,000 metric tons. By the end of 2008 (and the end of the copper boom), annual copper production had grown by 70 percent to more than 569,000 metric tons. Although total copper production in Zambia increased dramatically, two of the mines experienced large declines in production during this period because

\footnotetext{
${ }^{5}$ This figure reports the monthly world copper price and annual real GDP per capita in constant 2005 US\$. Copper price data come from the International Monetary Fund (IMF) database. The copper price series in this database is the London Metal Exchange (LME) spot price for grade A cathode at European ports. Real GDP per capita data (in constant prices) come from, "Alan Heston, Robert Summers and Bettina Aten, Penn World Table Version 6.3, Center for International Comparisons of Production, Income, and Prices at the University of Pennsylvannia, August 2009."

${ }^{6}$ Although the world copper price fell dramatically at the onset of the global economic recession of the late 2000 s, the sexual behavior and copper output data I use in the empirical analysis only capture the boom years and several pre-boom years.

${ }^{7}$ The other countries that produce more copper than does Zambia are the United States (1,220,000 metric tons), Peru (1,049,000 metric tons), Australia (859,000 metric tons), China (844,000 metric tons), Indonesia (816,000 metric tons), and Russia (675,000 metric tons).
} 
they began to run out of copper. ${ }^{8}$ Figure 3 shows annual copper mining production in Zambia from 2000-2008, disaggregated by depleting and non-depleting mines. For the depleting mines, Bwana Makuba mine in Ndola and Nchanga mine in Chingola, total output actually began to decline around the onset of the world copper price shock. ${ }^{9}$ In contrast, total production among the remaining nine mines rose sharply shortly after the world copper price shock began. Although output at the non-depleting mines was flat between 2003 and 2004, it increased by more than sixty percent in 2005 .

More generally, there was substantial heterogeneity across the full set of mining cities in the change in output associated with the world price shock. Figure 4 shows annual copper production by mining city from 2000-2008. The biggest increase in output associated with the copper price shock, in Solwezi in Northwestern Province, was an order of magnitude larger than the next largest increase. Similarly, the second largest increase, in Mufulira in Copperbelt Province, was roughly twice as large as the magnitude of the third largest increase. In several mining cities, output increased very little in comparison and output actually fell in Chingola and Ndola, the mining cities with the two depleting mines. This heterogeneity across mining cities suggests that a standard difference-in-differences approach to estimating the effects of the copper boom is not appropriate despite the large increase in aggregate copper production.

Employment in copper mining also increased substantially over this period, despite the relative capital intensity of large-scale copper mining. Figure 5 shows annual employment in copper mining from 1999-2008. Employment in copper mining grew by over 180 percent during the copper boom. Notably, the largest increase in employment in copper mining occurred in 2005, the same year in which output at the non-depleting mines increased most rapidly. By the end of the boom, roughly one in five adult males in copper mining cities was employed in copper mining. Similarly, the copper boom was associated with a large increase in aggregate output in Zambia. As shown in a previous figure (i.e., Figure 2) GDP per capita grew by 76 percent between 2003 and 2007.

\footnotetext{
${ }^{8}$ Personal communication with Alfred Phiri, Mining Economist, Zambia Ministry of Mines and Minerals Development.

${ }^{9}$ As we shall see in Figure 4, the decline in output at Nchanga mine in Chingola began shortly after the beginning of the copper price shock. The decline in output at Bwana Mankuba mine began around the middle of the copper price shock and was proceeded by a large increase in output relative to the pre-boom years.
} 


\section{Conceptual Framework}

There are several reasons to think that the copper boom raised incomes in mining cities and affected sexual behavior in these areas as well. An exogenous increase in the price of copper should have increased demand for labor among mining firms. Thus, the immediate effects of an increase in the world copper price likely were an increase in equilibrium employment in copper mining and an increase in the equilibrium wage. If the supply of mining labor were inelastic, then much of the benefit of the increased demand for mining labor would have accrued to existing mining employees. However, Figure 5 indicates that the benefits of the copper boom were enjoyed by new mining employees as well, as employment in copper mining nearly tripled. In addition, spill-over effects from increased copper production (e.g., increased demand for auxiliary services) mean that the copper boom likely raised the standard of living among individuals not employed in mining. Consistent with this hypothesis, anecdotal evidence from Zambian newspapers indicates that demand in copper mining cities for goods and services such as access road construction, taxis, restaurant meals, and laundry services is highly sensitive to local copper output. Similarly, the copper mining cities are home to a large manufacturing sector geared toward producing the smaller capital inputs required for large-scale copper mining, the demand for which is presumably highly correlated with local copper production.

These changes in income and relative prices would have affected behavior in several markets related to sexual activity. Changes in income and labor supply should have affected the dating and marriage markets. For example, if richer men are more highly valued in these markets, then we might observe an increase in dating and/or marriage among the male beneficiaries of the copper boom. A slightly different line of reasoning suggests that we might observe a substitution toward dating and away from marriage. Magruder's (2010) model of marital shopping predicts that an increase in life expectancy would increase the marital search period and reduce the rate of new marital formations.

The copper boom would have also affected the transactional sex market. Edlund and Korn (2002) argue that women in transactional sex markets earn a wage premium for the associated social stigma they incur in the marriage market. As the financial prospects associated with women's marital opportunities improve with the copper boom, one would expect a decreased willingness to supply transactional sex. Similarly, Robinson and Yeh (2010) show that negative economic shocks among commercial sex workers increase their willingness to supply particularly risky sex because 
of the desire to smooth consumption. Thus, rising incomes may have reduced willingness to supply risky sex on the extensive margin as well as the intensive margin. On the other hand, rising incomes may increase demand for transactional sex if transactional sex is a normal good.

There are several other possible effects of the copper boom. First, in Oster's (2009b) model of demand for risky behavior, rising incomes increase the continuation value of life, increasing the expected marginal cost of risky sex and reducing the equilibrium quantity of risky sex. Second, in a labor supply model where individuals choose effort to allocate to various tasks, an increase in copper mining employment and wages may be associated with increased effort exerted in the formal labor market and decreased effort exerted in marital search and sexual activity. Third, the increase in economic opportunities in mining cities may have induced labor migration to the mining cities. Increased in-migration likely affects the supply of sexual activity and demand for sexual activity.

\section{Data and Descriptive Statistics}

The individual and household level data for this analysis come from two sets of repeated crosssectional nationally representative household surveys: the Demographic Health Surveys (DHS) and the Zambia Sexual Behavior Surveys (ZSBS). I use the 2001 and 2007 survey rounds of the DHS and the 2003 and 2005 survey rounds of the ZSBS. These data include information on sexual behavior, consumer durable ownership, and migration status. In addition, I use administrative records on the location of the primary sampling units in these surveys to calculate relatively precise measures of the location of each survey household. ${ }^{10}$ This process yields 3,643 individuals in the 2001 DHS, 4,150 individuals in the 2003 ZSBS, 3,744 individuals in the 2005 ZBS, and 13,609 individuals in

\footnotetext{
${ }^{10}$ The nature of the spatial information in these surveys likely introduces bias toward zero in the estimates of the effect of the boom on material standard of living and sexual behavior in mining cities. For the ZSBS and the 2001 DHS, I use information on the respondent's Standard Enumeration Area (SEA) of residence to define the precise location of the respondent as the centroid of this SEA. Because these administrative units were designed to capture approximately 1,000 individuals, they tend to be quite small in urban areas. Hence, this method should produce location calculations indicating with a relatively high degree of accuracy which ZSBS and 2001 DHS respondents reside in mining areas. However, the 2007 DHS contains slightly different spatial information. Instead of revealing the respondent's SEA of residence, the 2007 DHS provides GPS data points that are intentionally measured with error for each respondent to address privacy concerns associated with the HIV testing module in this DHS. In the Zambia 2007 DHS, these data points were generated by adding a random vector with length drawn from a uniform distribution on 0 to 10 kilometers to the latitude and longitude of the centroid of the SEA of residence.
} 
the 2007 DHS. ${ }^{11}$

These surveys capture several dimensions of sexual behavior. In addition to standard demographic questions about marital status and pregnancy, the surveys ask respondents to enumerate up to their last three sexual partners in the twelve months prior to the survey date. I use these partner histories to construct indicator variables for whether the respondent had any sexual partner in the past twelve months and whether the respondent had multiple partners in the past twelve months. All of the surveys ask the respondent whether they used a condom the last time they had sex with a given partner in the past twelve months and I use this information to construct a measure of the proportion of sex acts that were unprotected conditional on reporting a sexual encounter in the past twelve months. The ZSBS asks all respondents whether they exchanged sex for money (or money for sex) in the past twelve months and the DHS asks male respondents this same question. I use this information to construct an indicator variable equal to one if an individual reported engaging in transactional sex. The surveys ask respondents when was the last time they had sex and I construct an indicator variable for whether they had sex in the past month. Finally, as an additional measure of risky sexual behavior the surveys (aside from the 2001 DHS) ask respondents whether they consumed alcohol before they had sex and I construct an indicator variable equal to one if they did so at some point in the twelve months leading up to the survey date.

Table 1 shows the gender-specific age profiles for each of these measures of sexual behavior. For the moment, I focus on describing some basic facts about gender and age differences in sexual behavior so I pool all four of the survey rounds to calculate sample means. Three key facts emerge from this analysis and will aid in the interpretation of the subsequent regression results. First, premarital sex is an important part of sexual activity. For example, only 20 percent of females age 15-19 are married yet 42 percent report having a sexual partner in the past twelve months. ${ }^{12}$

\footnotetext{
${ }^{11}$ The DHS and ZSBS survey females age 15-49 and males age 15-59. The 2001 DHS oversamples females by surveying only females in some households and not surveying men in these households. I exclude these female-only oversampled households from the analysis to avoid complications associated with creating ad hoc sample weights. In addition, the digitized census map provided by the Zambia Central Statistical Office, which I use to identify the location of the primary sampling units for the respondents in the 2001-2005 survey rounds, is missing approximately seven percent of the Statistical Enumeration Areas (SEAs) in Zambia. Thus, I am unable to identify the precise location of 6.58 percent of the 2001-2005 survey respondents and exclude these respondents from the empirical analysis.

${ }^{12}$ Although these data are not presented in Table 1, forty-six percent of unmarried males and thirty-seven percent of unmarried females report having a sexual partner in the past 12 months. Over 98 percent of married males and over 97 percent of married females report having a sexual partner in the past 12 months.
} 
Second, the likelihood of engaging in the riskiest sexual behaviors (i.e., multiple partnerships and transactional sex) is greatest among younger age groups (i.e., females age 15-19 and males age 20-29). Third, most females are married by their early twenties and most males are married by their late twenties, potentially constraining their ability to adjust their behaviors in response to the copper boom. ${ }^{13}$

Because my main empirical strategy relies partly on comparing changes in sexual behavior in mining cities during the copper boom to changes in sexual behavior elsewhere, it is useful to examine possible differences between these areas. Table 2 displays basic development indicators, demographic characteristics, and measures of sexual behavior in the copper mining cities, in the rest of Zambia, and in districts on the copper transportation routes. ${ }^{14} \mathrm{I}$ define a mining city as the area encompassed by a circle with a 10 kilometer radius located at the approximate centroid of the urbanized area. This implementation captures all of the urban area (i.e., area contiguously populated with structures) visible in satellite imagery for each of the nine copper mining cities in Zambia.

As shown in the first two columns in Table 2, residents of mining cities enjoy a higher standard of living than does the rest of Zambia. For most of the measures of material standard of living, households in mining cities are approximately twice as likely to report ownership than are households in the rest of Zambia. ${ }^{15}$ For measures such as motorcycle ownership, these differences disappear, partly because motorcycles are extremely rare in Zambia.

Rural-to-urban migration in Zambia means that residents of mining cities are more likely to be migrants (22 percent) than are residents of the rest of Zambia (17 percent). Interpreting the level of these figures requires caution because the measure of migration is based on whether the individual has lived in the same household location for at least a year or not. Thus, this measure

\footnotetext{
${ }^{13}$ At least two other points are worth noting. First, for the riskiest sexual activities, there are large differences by gender in average self-reported sexual activity. Gersovitz et al (1998) show that females under-reporting sexual activity and/or males over-reporting sexual activity is more likely to explain these gender differences in sexual behavior than is the existence of a small group of high sexual frequency women not captured by the survey. Second, $32 \%$ of females report being pregnant in the 12 months prior to the survey date, a figure that seems slightly high compared to the estimate total fertility rate in Zambia, 5.91 (Fortson 2009). This suggests that respondents may interpret the "12 months" prior to the survey as a period longer than 12 months.

${ }^{14}$ There are 72 districts in Zambia and the copper transportation routes pass through 19 of these districts. The districts on the copper transportation routes are: Chibombo, Chinsola, Choma, Isoka, Kabwe, Kafue, Kalomo, Kapiri Mposhi, Kasama, Kazungula, Livingstone, Lusaka, Masaiti, Mazabuka, Mkushi, Monze, Mpika, Nakonde, and Sernje.

${ }^{15}$ 'Floor" is an indicator variable for improved (i.e., brick, concrete, tile, or wood) floor.
} 
defines anyone who has relocated within a given city or village as a migrant even if they lived in that community for their entire life.

Individuals in mining cities appear to engage in less sexual activity than individuals in the rest of Zambia. The likelihood of having any partner in the past twelve months, having multiple partners, having sex in the past month, and pregnancy rates are lower in mining cities than in the rest of Zambia, as are marital rates. Rates of transactional sex and unprotected sex are approximately the same in mining cities and in the rest of Zambia. The single exception to this general pattern is alcohol use before sex.

HIV prevalence is higher in mining cities (16.3 percent) than in the rest of Zambia (14.5 percent). Although lack of data on changes in HIV prevalence at the sub-province level means I cannot directly examine the effect of the copper boom on HIV prevalence, there exist data on HIV status in the 2007 DHS at the individual level so I am able to calculate HIV prevalence in mining cities and in the rest of Zambia. Higher HIV prevalence in mining cities might seem surprising given that the level and riskiness of sexual activity is not higher in mining cities than in the rest of Zambia. However, as we shall see momentarily, sexual activity is similarly lower, and HIV prevalence is similarly higher, in the other urban areas in Zambia (i.e., districts along the main transportation routes), as compared to the non-mining regions of Zambia as a whole. This suggests that the level of urbanization (or population density) is an important determinant of HIV prevalence, an observation that is consistent with epidemiological models of HIV transmission.

Districts on the copper transportation routes are more similar to the mining cities than is the rest of Zambia as a whole. Column (3) in Table 2 shows the average characteristics of districts on copper transportation routes. Although the mining cities are still richer than these districts, the divide is smaller for all consumer durable ownership rates except motorcycle ownership. Likewise, residents of these districts have similar average demographic characteristics as mining cities. Sexual behavior in districts on copper transportation routes is also closer to that in mining cities than sexual behavior in the rest of Zambia as whole. HIV prevalence in these districts is virtually the same as in mining cities.

Monthly data on mine-level copper output come from the Ministry of Mines and Minerals Development. These data are available for the period January 2000 through December 2008. ${ }^{16}$

\footnotetext{
${ }^{16}$ Mine-level output data are missing for various months for various mines. When these missing data are not known to be due to a mine closing (or a delayed opening), mine-level output is re-constructed using a simple linear interpolation between the two bounding data points. In total, I interpolate 128 mine-months, or slightly less than
} 
Although I would like to complement the analysis of the effect of copper output with an analysis of the effects of employment in mining and of wages in mining, these data are not available at the mine level. Reassuringly, the synchronous increases in output at the non-depleting mines and employment in copper mining shown in Figures 3 and 4 suggest that copper output and employment in copper mining are highly correlated.

\section{Empirical Strategy}

The main empirical strategy of this paper is to exploit plausibly exogenous spatial and temporal variation in the intensity of copper production during the boom to identify the effects on risky sexual behavior. A basic premise of this approach is that the intensity of the copper shock was greater in copper mining cities than in other areas, both directly because of the increase in copper production and indirectly because of spill-over effects into other local markets. Similarly, this approach treats heterogeneity across mining cities in the output response to the copper price shock as (conditionally) exogenous to the process determining sexual behavior. ${ }^{17}$

There remain two primary concerns about the ability of this strategy to identify the causal effect of the copper boom on sexual activity (or material standard of living) in mining cities. First, the copper boom may have affected sexual activity in non-mining areas as well, meaning that this strategy may yield a biased estimate of the effect of the copper boom on sexual activity in mining cities. I explore this possibility by examining the effect of excluding the non-mining areas most likely to be affected by the copper boom (i.e., the main transportation routes used for copper output) on the coefficient estimates. Second, there may have been unobservable shocks to sexual activity that were correlated spatially or temporally with changes in copper output. To address these concerns, I include district fixed effects and month times year fixed effects. Month times year fixed effects also capture any seasonal variation in sexual activity. In addition, the baseline empirical specification for the individual-level regressions includes gender and five-year age group fixed effects.

eleven percent, of mine-level copper output data. Because I examine the effect of total local copper output in the 12 months prior to the survey date on sexual behavior during that period, failing to interpolate these data (or, alternatively and more unreasonably, failing to treat the missing values as zeros) would drastically reduce the number of "treatment" observations.

${ }^{17}$ As discussed in Section 2, much of this heterogeneity was due to the fact that two of the mines began to run out of copper during this period. 
My baseline empirical specification reflects this focus on isolating plausibly exogenous spatial and temporal variation in the intensity of copper production. Moreover, it exploits the availability of monthly mine level copper output data. As discussed in Section 2, measuring the effects of the intensity of local copper output instead of simply examining the difference between mining cities and non-mining areas in average behavior before and during the boom is particularly important in this setting because of substantial variation across mines in the intensity of the boom. This approach is virtually identical to that in Ruhm (2000), Ruhm (2003), Dehejia and Lleras-Muney (2004), and Ruhm (2005), studies that examine the effects of state-level unemployment rates on health in the United States. Likewise, this approach is similar in spirit to the difference-in-differences approaches in Bleakley (2007), Fortson (2009), Fortson (2010), and Lucas (2010), approaches that focus on estimating the effects of health shocks using variation in the shock on the intensive margin. ${ }^{18}$ The primary regression equation is:

$$
y_{i j k t}=\text { alocalmine }_{i j}+\text { Blocalboomoutput }_{i j k t}+X_{i j k t}^{\prime} \Gamma+\mu_{j}+\eta_{k t}+\epsilon_{i j k t}
$$

where $y_{i j k t}$ denotes the outcome (i.e., measure of sexual activity in the past twelve months, measure of contemporaneous material standard of living, or migration status) for individual $i$ (or household i) residing in district $j$ in month $k$ in year $t$ localmine $_{i j}$ is an indicator variable equal to one if the respondent resides in a mining area, localboomoutput $t_{i j k t}$ measures total boom-era copper output in the area around the respondent in the twelve months leading up to the interview date, $X_{i j k t}^{\prime}$ includes the vector of individual-level controls, $\mu_{j}$ are district fixed effects, and $\eta_{k t}$ are month times year fixed effects. $X_{i j k t}^{\prime}$ also includes a measure of total pre-boom copper output in the area around the respondent in the twelve months leading up to the interview date. ${ }^{19}$ For respondents from the 2005 ZSBS and 2007 DHS, all copper output produced in the twelve months leading up to the interview date was boom-era copper output. For the 2001 DHS and 2003 ZSBS, all copper output

\footnotetext{
${ }^{18}$ Ruhm (2000), Ruhm (2003), Dehejia and Lleras-Muney (2004), and Ruhm (2005) use a regression specification in which the state-level unemployment rate is the independent variable of interest and control for state fixed effects and time fixed effects. Bleakley (2007), Fortson (2009), Fortson (2010), and Lucas (2010) all use a regression specification where the independent variable of interest is a "post" indicator variable interacted with a continuous measure of treatment intensity.

${ }^{19}$ A specification that restricts the effects of pre-boom and boom-era copper output to be equal yields very similar estimates to those for $\beta$ presented in the current analysis. This finding is likely due to the fact that the majority of variation in copper output in the period captured in these data occurs during the boom period.
} 
produced in the twelve months leading up to the interview date was pre-boom copper output. To address the potential problem of serial correlation in the dependent variable I follow Bertrand et al (2004) and cluster standard errors by district, the geographic unit that most closely matches the level at which copper output varies.

The baseline specification treats the respondent as residing in a mining area if they reside within 10 kilometers of the center of a mining city. As discussed in Section 2, for each of the large-scale copper mines in Zambia there is a relatively large urban area located at (or very close to) to the mine. The effect of copper mining on behavior operates through markets and the urban area near each mine is a spatial approximation of the relevant market. To capture this dynamic, I assign the location of each mine to be the approximate centroid of the nearest urban area. Thus, in practice the 10 kilometer radius means that the regressions compare individuals living in these urban areas at the mines to individuals living elsewhere in Zambia.

This specification imposes a couple of simple restrictions that facilitate the exposition of the empirical results. First, in the absence of district fixed effects, equation (1) imposes the restriction that living within 10 kilometers of the center of a mining city has the same relationship with the outcome of interest (e.g., transactional sex) regardless of the identity of the mine. Including district fixed effects relaxes this restriction somewhat under the assumption that any heterogeneity across mines in this relationship is time invariant. Second, equation (1) imposes the restriction that changes in copper output within 10 kilometers of an individual have the same effect on the outcome of interest regardless of the identity of the mining city. Alternatively, I am estimating the average effect of changes in copper output across the eleven mines.

Before proceeding to the main empirical analysis, it is useful to investigate pre-boom trends in material standard of living, sexual behavior, and migration in mining cities and non-mining areas. I use the subset of data that are from the pre-boom period (i.e., the 2001 DHS and the 2003 ZSBS) to estimate a version of equation (1) which omits the measure of copper output (i.e., localboomoutput $t_{i j k t}$ ) and includes a secular linear trend and a mining city specific linear trend. Panel A in Table 3 presents evidence on pre-boom trends in consumer durables ownership by reporting the coefficient estimates for the two linear trends. There is little empirical support for the hypothesis that consumer durables ownership rates were increasing in mining cities relative to non-mining areas prior to the boom. For none of the consumer durables is the mining city specific trend statistically significant and in many cases it is negative. Panel B repeats this analysis for sexual behavior and migration. Again, the results fail to provide broad support for the hypothesis 
that sexual behavior (or migration) in mining cities and non-mining areas were on different preboom trends. Although the probability of having any partner appears to have been increasing in mining cities relative to non-mining areas, for none of the other measures of individual behavior is the mining city specific trend statistically significant. Moreover, in some cases the mining city specific trend is positive and in others it is negative. Overall, these results appear to support the central identifying assumption underlying my main empirical strategy. However, less than three years may be too short of an interval over which to accurately identify any pre-boom trends. ${ }^{20}$

\section{Results}

I begin the empirical analysis by examining the effect of the copper boom on consumer durable ownership. This analysis illustrates the magnitude and spatial extent of the copper boom. Then I examine the effect of the copper boom on migration and sexual behavior. As part of this analysis, I conduct a variety of robustness checks and explore heterogeneity by gender and age in the effects of the copper boom. Finally, I examine the role of selective in-migration in explaining these results.

\subsection{The Copper Boom and Household Consumer Durable Ownership}

The regression results indicate that the copper boom increased the standard of living of households in mining cities. Estimates of the effects of boom-era local copper output on consumer durable ownership appear in Table 4. All specifications include district fixed effects and month times year fixed effects. All specifications control for whether the respondent resides in a mining city and for pre-boom local copper output. Standard errors are clustered by district of residence.

Panel A presents the results from the baseline specification. These estimates indicate that the copper boom increased household ownership rates in mining cities for many consumer durables, including refrigerators, televisions, and cars. ${ }^{21}$ The effects are statistically significant at the 5 (or 1 percent) level and, at least in the case of refrigerators and televisions, are relatively large. The estimates indicate that a one standard deviation increase in copper output in the past year within

\footnotetext{
${ }^{20}$ Information on risky sexual behavior is available in the 1996 Zambia Demographic Health Survey. Unfortunately, administrative records for the primary sampling units in that survey do not exist so it is not possible to identify who lives in a mining cities and who does not.

${ }^{21}$ The baseline specification does not provide special treatment for the depleting mines. However, restricting attention to the effects of boom-era local copper output produced at non-depleting mines generates point estimates (and associated standard errors) that are virtually identical to those presented in Panel A.
} 
10 kilometers of a household (i.e., 21,000 metric tons) increased ownership rates for refrigerators and televisions by roughly 4 to 5 percentage points. In relative terms, these are fairly large effects. For example, a one standard deviation increase in copper output increased the probability of owning a television by approximately 20 percent relative to the average for Zambia as a whole. Although the coefficient estimates for consumer durables other than refrigerator, television, and car are not statistically significant, generally they are positive and relatively large. The two exceptions to this pattern are motorcycles and bicycles, vehicles which are substantively different from the other consumer durables measured in the DHS and ZSBS. Very few Zambians own motorcycles and bicycles may not be normal goods in this income range. ${ }^{22}$

In Panel B, I examine the sensitivity of the estimated effect of local boom-era copper output to including a secular linear trend and a mining city specific linear trend. Including these linear trends should address concerns that the baseline estimates may simply reflect the existence of different trends in consumer durables ownership in mining and non-mining areas. The coefficient estimates in Panel B suggest that the effects estimated using the baseline specification might be underestimates of the effects of the copper boom on material standard of living in mining cities. Not only do the estimates in the refrigerator and television regressions increase in magnitude (while remaining statistically significant at the 5 percent level), but the floor and radio estimates increase in magnitude and become statistically significant at the 5 and 1 percent levels, respectively. In contrast, the coefficient estimate in the car regression falls by approximately 50 percent and becomes statistically insignificant. Perhaps surprisingly, the coefficient estimate in the motorcycle regression suggests that copper output reduced motorcycle ownership. However, motorcycles are extremely rare in Zambia and the magnitude of this effect is quite small in absolute value.

The coefficient estimates presented thus far may be underestimates of the effect of the copper boom on the material standard of living in mining cities. If the copper boom raised the material standard of living in non-mining areas as well, then the estimates in Panels A and B may be biased downwards. To explore this possibility, Panel $\mathrm{C}$ excludes respondents who live along the copper transportation corridors. These corridors are: (i) the route south from the copper mining region to Lusaka and on to Livingstone, and (ii) the route from the copper mining region to the east and on past Kasama. Households in these areas would appear to be those households outside of the

\footnotetext{
${ }^{22}$ Average vehicle ownership rates are consistent with this interpretation. As shown in Table 2, close to zero percent of households own a motorcycle and bicycles are the only consumer durable for which ownership rates are lower in copper mining cities than elsewhere in Zambia.
} 
copper mining region most likely to have benefited from increased copper production.

The estimated effects of the copper boom on the material standard of living in mining cities are robust to excluding districts along the copper transportation corridor. All of the effects identified in the baseline specification (i.e., Panel A) are present in Panel C. Moreover, the point estimates are very close to those in the baseline specification. This suggests that districts along transportation corridors did not benefit substantially from the copper boom.

As a final robustness check, I examine the effect of the value of copper produced on material standard of living, rather than the quantity of copper produced. Panel D presents the results of this exercise. The independent variable of interest, "CU value, $0-10 \mathrm{~km}$ ", is simply the LME spot price for a metric ton of grade A cathode at CIF European ports (measured in (2005) US\$ '0,000s) multiplied by the independent variable of interest in the previous panels (i.e., metric tons of boom-era output produced within 10 kilometers of the respondent in the twelve months prior to the survey date). Again, the large, positive, and (generally) statistically significant coefficient estimates are consistent with the claim that the copper boom raised material standard of living in mining cities.

\subsection{The Copper Boom and Individual Behavior: Sexual Activity and Migration}

\subsubsection{Baseline Results}

The baseline regression results indicate that the copper boom reduced transactional sex and multiple partnerships in mining cities. Estimates of the effects of boom-era local copper output on sexual activity appear in Table 5. All specifications include district fixed effects and month times year fixed effects. All specifications control for whether the respondent resides in a mining area and preboom local copper output, as well as the respondent's gender, and five-year age group. Standard errors are clustered by district of residence.

Panel A presents the results from the baseline specification. These estimates indicate that the copper boom reduced transactional sex and multiple partnerships in mining cities. ${ }^{23}$ A one standard deviation increase in boom-era copper output in the past year within 10 kilometers of a household (i.e., 21,000 metric tons) reduced rates of transactional sex and multiple partnerships by between one-half and one percentage point each. Although the magnitude of these effects is not

\footnotetext{
${ }^{23}$ The baseline specification does not provide special treatment for the depleting mines. However, restricting attention to the effects of boom-era local copper output produced at non-depleting mines generates point estimates (and associated standard errors) that are virtually identical to those presented in Panel A.
} 
particularly large in absolute terms, they are statistically significant at the 5 percent confidence level and large in relative terms. An increase of one standard deviation in boom-era copper output in the past year within 10 kilometers of a household reduced rates of transactional sex by nearly 20 percent and of multiple partnerships by nearly 10 percent. ${ }^{24}$ Among the less risky (and somewhat less reliable) auxiliary measures of sexual behavior, the copper boom reduced alcohol consumption at sex (significant at the 10 percent level) and the likelihood of having had sex in the past month (significant at the 1 percent level). ${ }^{25}$ For the remaining measures of sexual behavior, none of the reported coefficient estimates are statistically significant, although the sign on boom-era local copper output is always negative, consistent with a reduction in risky sexual activity.

Panel B expands the baseline specification to include a secular linear trend and a mining city specific linear trend. The results of this exercise are broadly consistent with the reduction in particularly risky sexual behaviors documented in Panel A. For example, the estimated effects for transactional sex, alcohol consumption at sex, and sex in the past month are roughly similar in magnitude to those in Panel A and are statistically significant at the 5 percent level. In addition, the estimates indicate that the copper boom reduced the likelihood of unprotected sex conditional

\footnotetext{
${ }^{24}$ In principle, HIV prevention and treatment efforts on the part of mining companies is one channel through which the copper boom may have affected sexual activity. However, there is little anecdotal or statistical evidence to support the hypothesis that the scale, scope, or intensity of HIV prevention and treatment efforts on the part of mining companies was correlated with copper output. Fraser and Lungu (2007) note that: (i) the mining companies that currently have the most comprehensive HIV/AIDS policies implemented these prior to the boom (i.e., 2002) rather than during the boom, and (ii) the mining companies' main HIV/AIDS policy is treatment (not prevention), partly because of a failed mandatory (i.e., involuntary) HIV testing program at one of the large mines in 2001. To provide statistical evidence on this question, I estimated equation (1) using separate indicator variables for knowledge of each of the three ABCs (i.e., abstain, be faithful, and correct and consistent condom use) as effective HIV prevention methods as the outcomes of interest. The regression results fail to provide empirical support for the hypothesis that boom-era local copper output was associated with increased knowledge of any of the three main HIV prevention methods, suggesting that increased exposure to or intensity of mining company HIV/AIDS interventions is not the mechanism driving these results.

${ }^{25}$ The response to the copper boom may have differed by marital status. However, the fact that local copper output reduced marital rates suggests that the decrease in marital rates may have been one channel through which the boom affected sexual behavior and that these regressions should not control for whether the respondent is married. Nonetheless, in regressions not reported in the tables I examine the effect of controlling for marital status and of allowing the effect of local copper output to vary by marital status. These results indicate that controlling for marital status does not substantially affect the results and that the response did not vary by marital status. Although the effect of local copper output on transactional sex for non-married respondents is slightly larger than that for married respondents, the difference is not statistically significant.
} 
on having sex (significant at 10 percent level), reduced pregnancy rates (significant at 10 percent level), and reduced marital rates (significant at 1 percent level). Although the point estimate is larger in magnitude in Panel B than in Panel A, the estimated effect on the likelihood of having multiple partners is no longer statistically significant.

The coefficient estimates in Panels A and b might reflect an increase in sexual activity in nonmining areas rather than a decrease in sexual activity in mining cities. Oster (2009a) provides evidence from Sub-Saharan Africa that increases in exports and associated trucking activity are linked to increases in HIV incidence. If the copper boom induced an increase in sexual activity along copper transportation routes, the regressions in Panels A and B might show a negative effect of copper output on sexual activity in mining cities even if actually there was no effect on sexual activity in mining cities. To explore this hypothesis, Panel $\mathrm{C}$ excludes respondents who live along the copper transportation corridors.

The estimated effects of the copper boom on transactional sex and multiple partnerships in mining cities are relatively robust to excluding districts along the copper transportation corridor. Although the effect on the likelihood of having had sex in the past month is now only statistically significant at the 10 percent level, all of the effects identified in the baseline specification (i.e., Panel A) are present in Panel C. In particular, a one standard deviation in boom-era local copper output continues to reduce rates of transactional sex and multiple partnerships by between approximately 10 and 20 percent (significant at the 5 percent level).

Panel D presents results from sexual behavior regressions that use the value of copper produced within 10 kilometers of the respondent instead of the quantity of copper produced. As discussed in the previous section, the results from the consumer durables regressions indicate that the value of copper produced locally had a large and significant effect on the material standard of living, similar to the effect of the quantity of copper produced. Thus, given the other results presented in this analysis, it is not surprising that the results of the transactional sex and multiple partnerships regressions (significant at the 1 percent level) are robust to this substitution, as are the regressions for virtually all of the other sexual behavior measures. The single exception is that the sign on value of boom-era local copper output becomes positive in the proportion unprotected regression, although the coefficient estimate is not statistically significant.

As part of the analysis of the individual-level behavioral response to the copper boom, I examine the effect of the copper boom on in-migration. Column (9) of Table 5 presents the in-migration results. As shown in Panel A, the copper boom induced in-migration to the copper mining cities. A 
one standard deviation increase in boom-era local copper output in a given mining city increased the probability a resident was a recent in-migrant by approximately 2 percentage points (significant at the 1 percent level), or by roughly 10 percent as compared to the baseline proportion of in-migrants. The migration results in Panels B through D show similarly strong and statistically significant effects (significant at the 1 percent level). Because of the large and statistically significant increase in in-migration generated by the copper boom, I investigate the role of in-migration in explaining the sexual behavior results after I finish examining heterogeneity by gender and age in the effect of the copper boom.

\subsubsection{Gender}

Although the copper boom reduced average risky sexual behavior in mining cities, males and females may not have responded to the copper boom in the same way. Table 6 allows the effect of boom-era local copper output on sexual activity to vary by gender of the respondent. The estimates suggest that the copper boom decreased sexual activity more for males than for females, although the gender difference tends to not be statistically significant and never indicates that the boom increased sexual activity.

By most measures of sexual behavior, the estimated effect of boom-era local copper output on the sexual activity of males is very close to that estimated in the baseline specification. For example, the point estimates indicate that a one standard deviation increase in copper output in the past year within 10 kilometers of a household (i.e., 21,000 metric tons) reduced rates of transactional sex by approximately 1 percentage point, or roughly 20 percent (significant at the 1 percent level). Although the point estimate in the multiple partners regression is no longer statistically significant, it is slightly larger in absolute value than that in the baseline specification. Overall, none of the estimated effects for males are smaller than those in the baseline specification, and the estimated effects for alcohol consumption at sex and sex in the past month are substantially larger than those in the baseline specification.

For the two particularly risky behaviors, transactional sex and multiple partners, the estimated effects for females are slightly smaller than those for males. However, these differences are not statistically significant. For other measures, such as alcohol consumption at sex and sex in the past month, the gender differences are large and statistically significant. In fact, these estimates indicate that the copper boom had no effect on alcohol consumption at sex and sex in the past month for females. In general, none of the differences by gender indicate a statistically significant 
increase in sexual activity among females as a result of the boom.

Although the presumption is that the vast majority of reported sexual activity in Zambia is heterosexual, this does not rule out differential effects by gender. There are at least three reasons why the estimated effects of the boom may vary by gender. First, the survey data may undersample high frequency females. It may be the case that under-sampled high frequency women are reducing their sexual activity by more than the women in the sample. Second, the available measures of sexual activity mostly capture the extensive margin of sexual behavior decision-making and do not capture the intensive margin. It may be the case that the intensive margin decreases more for women than for men. Third, as mentioned in a footnote in Section 4, Gersovitz et al (1998) demonstrate that the large gender difference in average levels of sexual activity that characterizes nationally representative sexual behavior surveys like the DHS and ZSBS suggests that females may under-report their levels of risky sexual behavior. The extremely low rates of transactional sex and multiple partnerships among women in the Zambia data (i.e., 2.8 percent and 1.7 percent, respectively) are consistent with this claim and also mechanically limit the scope for reductions among women in these behaviors.

As I demonstrate in the following section, the available evidence on this issue appears to point toward the reporting bias explanation. Pregnancy is the sexual behavior least susceptible to reporting bias because largely it is observable. The estimates presented in the following section indicate that the copper boom generated a large and statistically significant reduction in pregnancy rates among women age 15-19. Furthermore, consistent with the reporting bias explanation, aside from pregnancy rates, women in this age group largely fail to demonstrate sexual behavior changes in response to local copper output that are statistically different from women in other age groups.

Disaggregating the in-migration response by gender has little impact on the estimated effect of the copper boom. Although the effect is somewhat larger for males, the difference by gender is not statistically significant. This suggests that the copper boom attracted female and male in-migrants in roughly equal proportions.

\subsubsection{Age}

The large differences by age in sexual behavior displayed in Table 1 suggest that the effect of the copper boom on sexual activity may have varied across age groups. For example, rates of transactional sex are highest at younger age groups and decline precipitously with age. Table 7 examines this possibility by reporting the coefficient estimates for the interactions of the measure 
of boom-era local copper output with a female indicator variable, age-group indicator variables, and the interactions of these two sets of variables.

These estimates indicate that the largest effect of the copper boom on transactional sex was concentrated among younger males (significant at the 1 percent level). One explanation for this finding is that males age 20-29 have the highest rates of transactional sex and hence the greatest scope for reduction. The lower degree of heterogeneity in the effect of local copper output on multiple partnerships, an outcome with a flatter age profile, is consistent with this interpretation.

The overall body of evidence presented thus far indicates that the copper boom reduced particularly risky sexual behaviors and did not increase sexual activity on other margins. Thus, it is somewhat surprising that transactional sex actually increased for males age 15-19 (significant at the 5 percent level). However, the magnitude of the increase in transactional sex for males age 15-19 is relatively small. For example, it is only one-fifth of the estimated reduction in transactional sex for males age 20-29.

Consistent with the concentrated effect of the boom on transactional sex for males age 20-29, this demographic group also demonstrated one of the largest reductions in alcohol consumption at sex (significant at the 1 percent level). Similarly, males age 20-29 demonstrated the largest reduction in the likelihood of having any partner in the past twelve months (significant at the 1 percent level). Although the effects for this demographic group are not statistically indistinguishable from that for males age 15-19, males age 20-29 also reduced multiple partnerships and coital frequency in response to the boom (significant at the 1 percent level).

The large reduction in pregnancy rates among females age 15-19 corroborates the argument that the large (although not statistically significant) differences by gender in Table 6 are explained by attenuation toward zero due to females under-reporting sexual activity. Because it is an observable characteristic (at least in the later stages and often to the surveyor) and possibly a less stigmatized outcome, women are seemingly much less likely to prevaricate when reporting pregnancy within the past twelve months than when reporting other (often stigmatized) sexual behaviors. The coefficient estimate for local copper output for females age 15-19 (significant at 1 percent level) indicates that a one standard deviation increase in local copper output reduces pregnancy rates in this demographic group by approximately 4 percentage points (i.e., nearly a 20 percent reduction).

Disaggregating the in-migration response by the interaction of age and gender suggests that younger individuals may have been more likely to migrate to copper mining cities in response to the boom. Older males (e.g., ages 30-39 and 40-49) were slightly less likely to demonstrate a 
change in the probability of being an in-migrant than were males age 20-29. Similarly, females age 15-19 were more likely to demonstrate a change in the probability of being an in-migrant than were females in other age groups. However, none of these differences are statistically significant at conventional levels.

\subsection{Selection and Effects on Non-Migrants}

Substantial in-migration in mining cities induced by the copper boom raises two important points about the results presented thus far. First, selective in-migration may have contributed to the overall reduction in particularly risky sexual behavior due to the copper boom. Second, if selfreported sexual activity among in-migrants partly reflects the respondent's behavior in the previous (i.e., non-mining) location, then this may be driving the estimated effects of local copper output on sexual activity. This section addresses these issues in detail by comparing the behavior of inmigrants and non-migrants in mining cities, as well as by allowing the effect of the boom to vary by whether the respondent is a recent in-migrant to a mining area.

A comparison of means indicates that migrants in mining cities are less risky than non-migrants in mining cities. As shown in Table 8, migrants in mining cities are less likely to engage in transactional sex, engage in unprotected sex, consume alcohol at sex, have had sex in the past month, or be married. ${ }^{26}$ Differences between migrants and non-migrants in the likelihood of having had any partner or multiple sexual partners in the past twelve months are small or non-existent. The one measure of sexual activity by which migrants appear to be riskier than non-migrants is in the likelihood of being pregnant in the past twelve months. Consistent with their generally lower levels of sexual activity, migrants are less likely to be HIV positive.

Although copper boom induced in-migration is consistent with a compositional effect on sexual activity, the copper boom still may have affected the behavior of non-migrants residing in mining cities. To examine this hypothesis, I interact the measure of boom-era local copper output (i.e., CU output, $0-10 \mathrm{~km}$ ) with the measure of whether the respondent is a recent in-migrant (i.e., an indicator variable equal to one if the respondent has resided in the same household for less than one year). The coefficient on boom-era local copper output yields the estimated effect of the boom

\footnotetext{
${ }^{26}$ In Table 8, I define non-migrant as an individual who has resided in the same household for at least five years, ensuring that these are individuals who were not induced to move to mining cities because of the copper boom. In addition, I restrict the analysis of in-migrants in mining cities to those survey rounds (i..e., the 2005 ZSBS and the 2007 DHS) possibly including respondents induced to migrate to mining cities because of the copper boom.
} 
for non-migrants in mining cities.

Panel A in Table 9 presents the consumer durables results for this unrestricted specification. These regressions include the same set of controls as the baseline specification, as well as controls for in-migrant and in-migrant interacted with the indicator variable for mining city. The estimates are similar to those found in the baseline sample (i.e., the results presented in Table 4). Among non-migrants (i.e., individuals who have resided in the same household for at least one year), the copper boom had large effects on refrigerator, television, and car ownership (significant at the 5 percent level or smaller). The coefficient on the recent in-migrant interaction tends to be small, of varying sign, and sometimes statistically significant. In general, these results (unsurprisingly) confirm that non-migrants in mining cities did receive a positive economic shock and that the effect for recent in-migrants largely is statistically indistinguishable from that for non-migrants.

Before turning to the sexual behavior regressions, it is useful to note that the comparison of means in Table 8 also indicates that migrants in mining cities are younger than non-migrants in mining cities. Because the heterogeneity analyses presented thus far indicate that the behavioral response to the copper boom varied substantially across age groups, in the sexual behavior regressions that follow I allow the effects of local copper output on non-migrants and on migrants to vary by age of the respondent. In particular, as shown in Table 7, the effects of the copper boom on sexual behavior were largely concentrated among individuals under the age of thirty. Thus, I interact the measure of boom-era local copper output, the measure of whether the respondent is a recent in-migrant, and the interaction thereof with an indicator variable for whether the respondent is age $30-59$.

Panel B presents the sexual behavior results for this unrestricted specification. Again, these regressions include the same set of controls as the baseline specification, as well as controls for inmigrant and in-migrant interacted with the indicator variable for mining city. On the whole, these results reject the hypotheses that the reduction in risky sexual activity I document in the baseline specification was due solely to a compositional change in the population residing in mining cities or simply reflects the behavior of in-migrants prior to their arrival in mining cities. The estimated effect of boom-era local copper output on transactional sex for younger (i.e., age 15-29) non-migrants is similar to that in the baseline specification and is significant at the 1 percent level. Although the estimated effect for multiple partners is less precisely estimated than in the baseline specification, it is nearly twice as large as in the baseline specification (significant at the 10 percent level). For both of these measures older non-migrants (i.e., age 30-59) did not demonstrate a statistically significant 
response to the copper boom, a finding that is consistent with the heterogeneity analysis presented in Table 7. Likewise, the estimates indicate that the copper boom reduced pregnancy rates among younger non-migrant women (i.e., age 15-29), but not for older non-migrant women (i.e., age 30-49). As in the consumer durables regressions, the estimated effect for in-migrants is usually statistically indistinguishable from that for non-migrants. ${ }^{27}$

Overall, the analysis of recent in-migrants in mining cities provides little support for the notion that in-migration induced by the copper boom increased the propensity to engage in risky sexual activity in mining cities. In fact, copper boom induced in-migration in mining cities appears to have generated part of the reduction in rates of transactional sex and multiple partnerships. This finding may seem puzzling given the existing literature on the relationship between migration and risky sexual behavior. However, these in-migrants in Zambian copper mining cities may differ from the migrants examined in the existing literature on migration and HIV/AIDS. As shown in the consumer durables ownership rates in Table 8, the copper boom in-migrants appear to be as wealthy or wealthier than the (relatively rich, by Zambian standards) non-migrants in mining cities.

\section{Conclusion}

This paper provides some of the first microeconomic evidence on the effect of a large and sustained economic shock on risky sexual behavior. I exploit the dramatic increase in the world copper price in the early twenty-first century, a change that was exogenous to the process determining sexual behavior in Zambia, to provide evidence on the effects of increased production in a major sector of the Zambian economy on sexual behavior. I use newly assembled repeated cross-sectional sexual behavior survey data with a detailed geographic component collected before and during the copper boom and employ a host of spatial and temporal controls to address remaining concerns about identification.

In the setting I examine, Zambia during the early twenty-first century copper boom, a large positive economic shock to production in mining cities reduced transactional sex and multiple partnerships, two sexual behaviors that are particularly risky. Similarly, this economic boom reduced pregnancy rates among young women, the women most likely in general to report engaging in transactional sex and having multiple sexual partners. This suggests that the supply-side effects of rising

\footnotetext{
${ }^{27}$ Notable exceptions are that in-migrants age 30-59 reduced alcohol consumption at sex and the likelihood of having any partner in the past 12 months more than did other demographic groups.
} 
incomes and economic opportunities for women outside of sexual activity dominate demand-side effects, if any, among men of rising incomes and increased willingness-to-pay for sex.

These results may be broadly generalizable to predict the effects of economic booms or growth on risky sexual behavior in other very poor countries. Unlike stereotypical mining settings in many other parts of the world, the Zambian copper mines are located in relatively large urban areas with gender ratios very close to one. Thus, the effects of the quasi-experiment provided by the Zambian copper boom may resemble the effects of economy-wide growth on risky sexual behavior in very poor countries. This suggests that balanced economic growth in Sub-Saharan Africa may be an important factor in the fight against the HIV/AIDS pandemic. However, although the demographic structure of Zambian mining cities is approximately representative of many Sub-Saharan African countries rather than mining regions in particular, a host of contextual factors may condition the observed response in this study setting. Likewise, the effect of long-run economic growth on risky sexual behavior may differ from that of a long and sustained positive economic shock. Certainly additional research on this question is required. 


\section{References}

Beny, Laura and Lisa Cook. 2009. Metals or management? Explaining Africa's recent economic growth performance. American Economic Review: Papers \& Proceedings, 99(2): 268-274.

Bertrand, Marianne, Esther Duflo, and Sendhil Mullainathan. 2004. How much should we trust difference-in-differences estimates? Quarterly Journal of Economics, 119(1): 249-275.

Bleakley, Hoyt. 2007. Disease and development: Evidence from hookworm eradication in the American South. Quarterly Journal of Economics, 122(1): 73-117.

Central Statistics Office. 2005 Labor Force Survey. Government of Zambia.

Dehejia, Rajeev and Adriana Lleras-Muney. 2004. Booms, busts, and babies' health. Quarterly Journal of Economics, 1091-1130.

Dinkelman, Taryn, David Lam, and Murray Leibbrandt. 2007. Household and community income, economic shocks and risky sexual behavior of young adults: Evidence from the Cape Area Panel Study 2002 and 2005. AIDS, 21(supplement 7): S49-S56.

Dupas, Pascaline and Jonathan Robinson. 2011. The (hidden) costs of political instability: Evidence from Kenya's 2007 election crisis. University of California, Santa Cruz working paper.

Edlund, Lena and Evelyn Korn. 2002. A theory of prostitution. Journal of Political Economy, 110(1): 181-214.

Fenton, Lynda. 2004. Preventing HIV/AIDS through poverty reduction: The only sustainable solution. Lancet, 364: 1186-87.

Fortson, Jane. 2009. HIV/AIDS and fertility. American Economic Journal: Applied Economics, 1(3): 170-194.

Fortson, Jane. 2010. Mortality risk and human capital investment: The impact of HIV/AIDS in Sub-Saharan Africa. Review of Economics and Statistics, forthcoming.

Fraser, Alastair and John Lungu. 2007. For Whom the Windfalls? Winners and Losers in the Privatization of Zambia's Copper Mines. Lusaka, Zambia: Mine Watch Zambia.

Gertler, Paul, Manisha Shah, and Stefano Bertozzi. 2005. Risky business: The market for unpro- 
tected commercial sex. Journal of Political Economy, 113(4): 518-550.

Gersovitz, Mark, Jacoby, Hanan, Seri Dedy, F., Goze Tape, A.. 1998. The balance of self-reported heterosexual activity in KAP surveys and the AIDS epidemic in Africa. Journal of the American Statistical Association, 93(443): 875-883.

International Copper Study Group. www.icsg.org. Accessed January 2010.

Juhn, Chinhui, Sebnem Kalemi-Ozcan, Belgi Turan. 2009. HIV and fertility in Africa: First evidence from population based surveys. NBER Working Paper 12181.

Kolher, Hans-Peter and Rebecca Thornton. 2010. Conditional Cash Transfers and HIV/AIDS Prevention: Unconditionally Promising? BREAD Working Paper No. 283.

Lucas, Adrienne. 2010. Malaria eradication and educational attainment: Evidence from Paraguay and Sri Lanka. American Economic Journal: Applied Economics, 2(2): 46-71.

Lurie, Mark, Brian Williams, Khangelani Zuma, David Mkaya-Mwamburi, Geoff Garnett, Michael Sweat, Joel Gittlesohn, and Salim Abdool Karim. Who infects whom? HIV-1 concordance and discordance among migrant and non-migrant couples in South Africa. AIDS, 17: 2245-2252.

Mishra, Vinod, Simona Bignami-Van Assche, Robert Greener, Martin Vaessen, Rathavuth Hong, Peter Ghys, J. Ties Boerma, Ari Van Assche, Shane Khan, and Shea Rutstein. 2007. HIV infection does not disproportionately affect the poorer in Sub-Saharan Africa. AIDS, 21 (suppl 7): S17-S28. Oster, Emily. 2009a. Routes of infection: Exports and HIV incidence in Sub-Saharan Africa. Journal of the European Economic Association, forthcoming.

Oster, Emily. 2009b. HIV and behavior change: Why not Africa? University of Chicago working paper.

Panayotou, Theodore. 1979. OPEC as a model for copper exporters: Potential gains and cartel behavior. The Developing Economies, 17(2): 203-219.

Parkhurst, Justin. 2010. Understanding the correlations between wealth, poverty and human immunodeficiency virus infection in African countries. Bulletin of the World Health Organization, 88: 519-526.

Pindyck, Robert. 1978. Gains to producers from the cartelization of exhaustible resources. The 
Review of Economics and Statistics, 60(2): 238-251.

Robinson, Jonathan and Ethan Yeh. 2010. Transactional sex as a response to risk in Western Kenya. American Economic Journal, forthcoming.

Ruhm, Christopher. 2000. Are recessions good for your health? Quarterly Journal of Economics, 115(2): $617-650$.

Ruhm, Christopher. 2003. Good times make you sick. Journal of Health Economics, 22: 637-658.

Ruhm, Christopher. 2005. Healthy living in hard times. Journal of Health Economics, 24: 341-363.

Stuckler, David, Basu, Sanjay, McKee, Martin, and Mark Lurie. 2010. Mining and risk of tuberculosis in Sub-Saharan Africa. American Journal of Public Health, forthcoming.

United Nations Statistics Division. Commodity Trade Statistics Database. www.data.un.org. Accessed October 2009.

United States Agency for International Development (USAID). 2006. Zambia: Economic Performance Assessment. March, 2006.

Young, Alwyn. 2005. The gift of the dying: The tragedy of AIDS and the welfare of future African generations. Quarterly Journal of Economics, 120(2): 423-466. 
Figure 1: Spatial Distribution of Copper Mining in Zambia

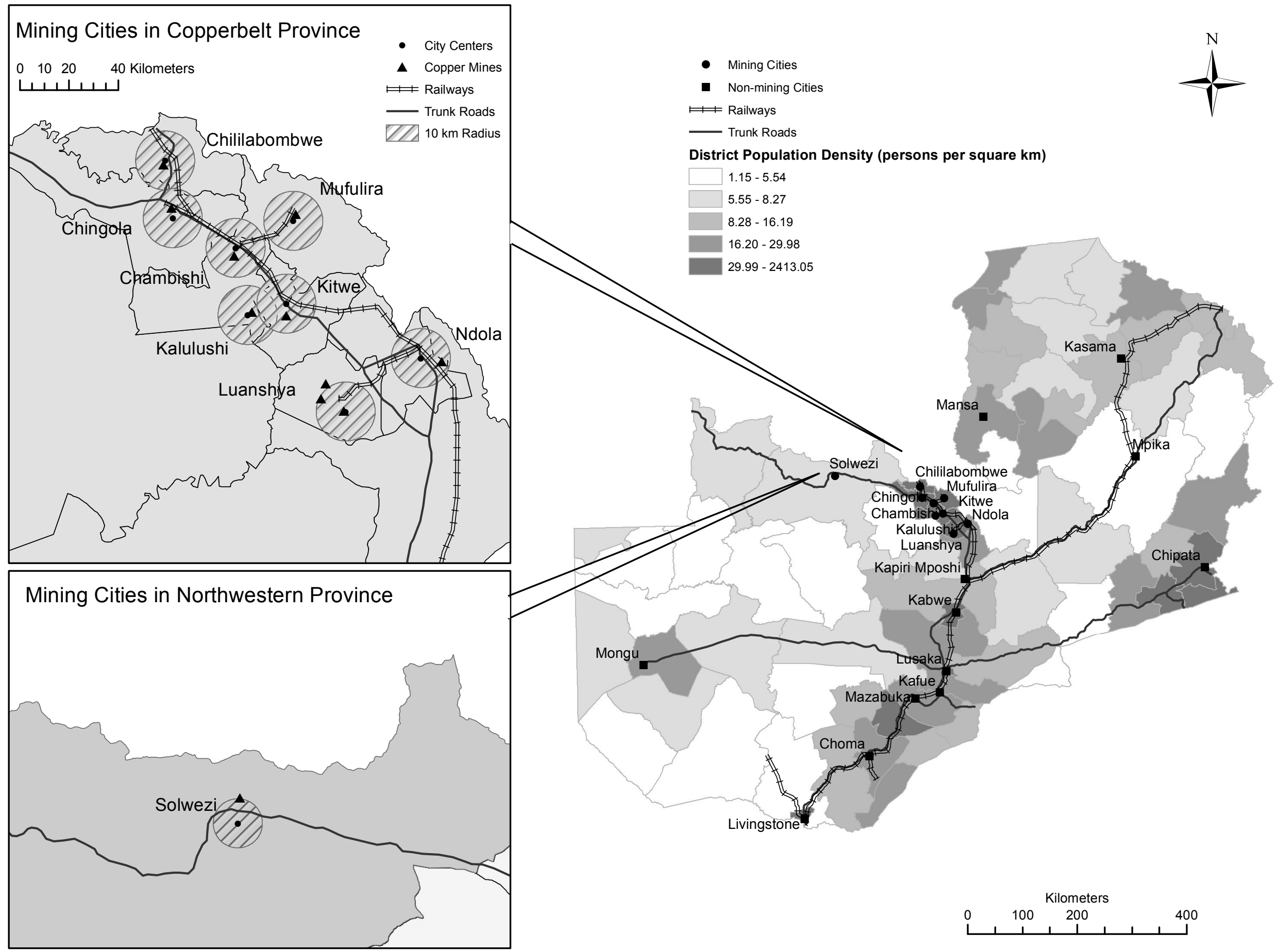


Figure 2: World Copper Price and Zambia GDP Per Capita, 1980-2010

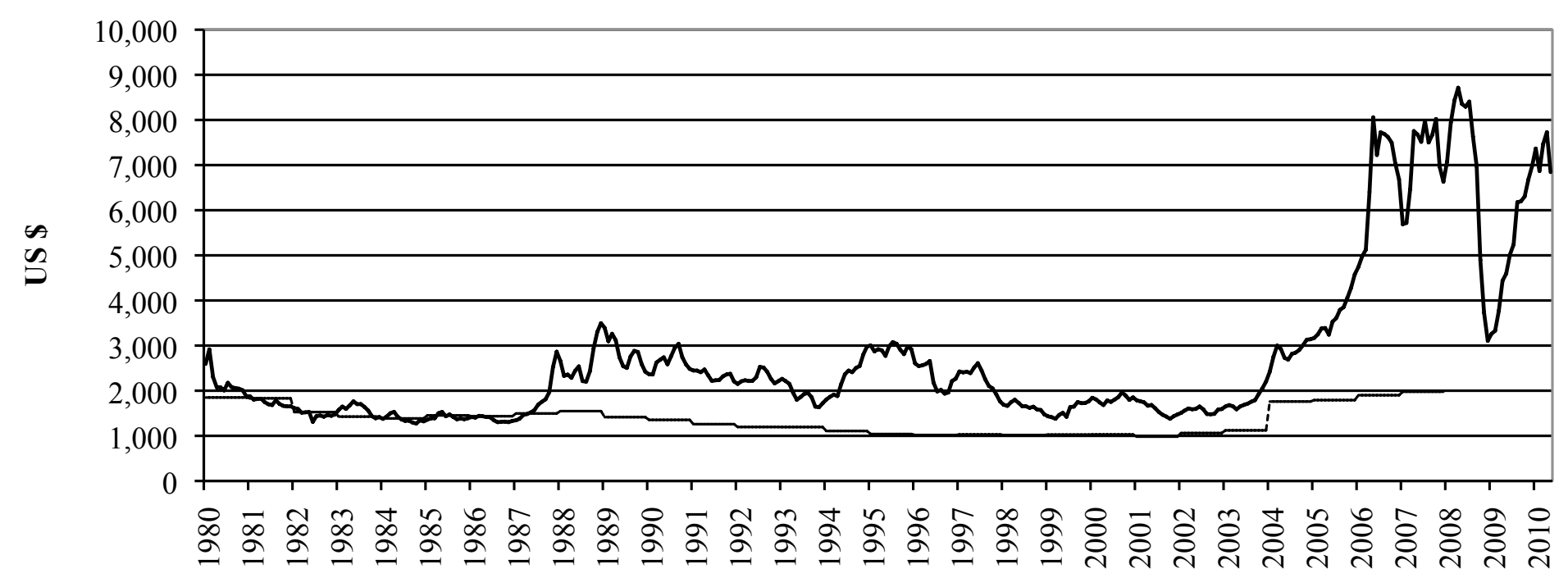

Year 
Figure 3: Copper Production, Zambia 2000-2008

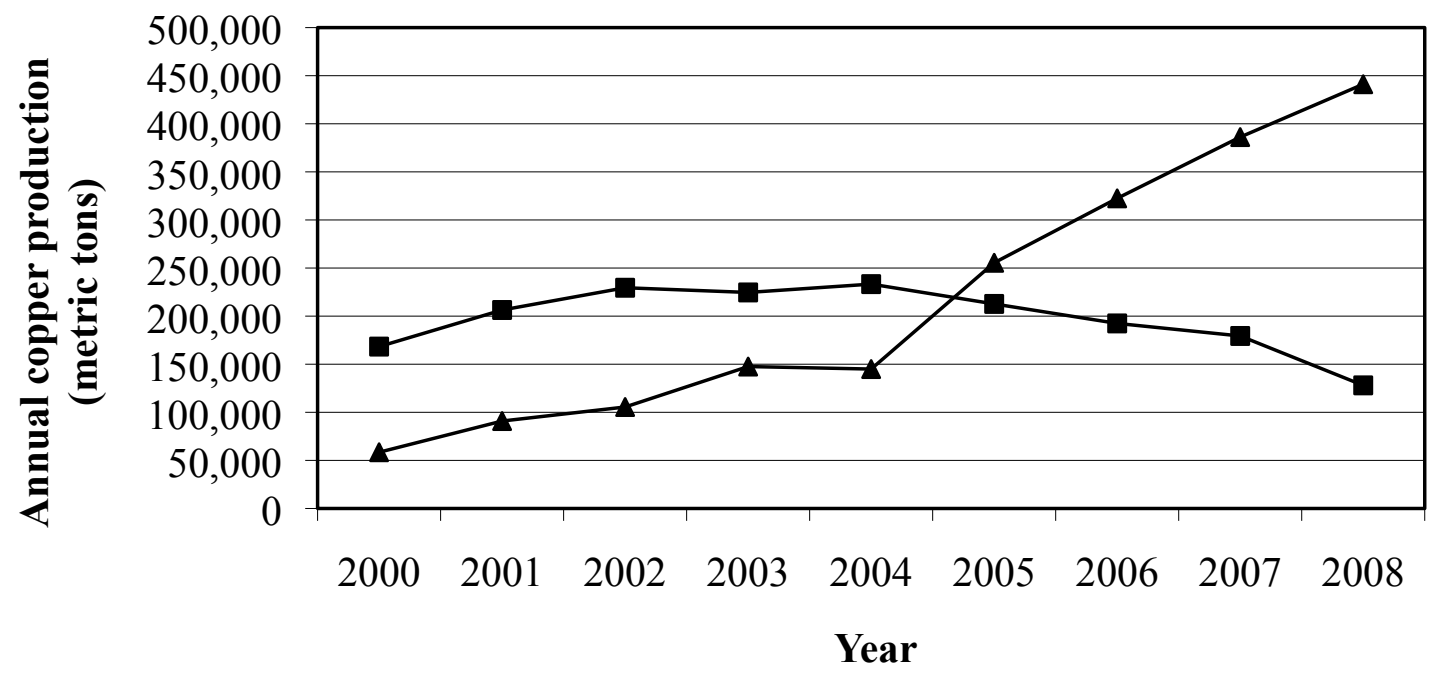

$\leftarrow$ non-depleting mines $\quad \rightarrow$ depleting mines 


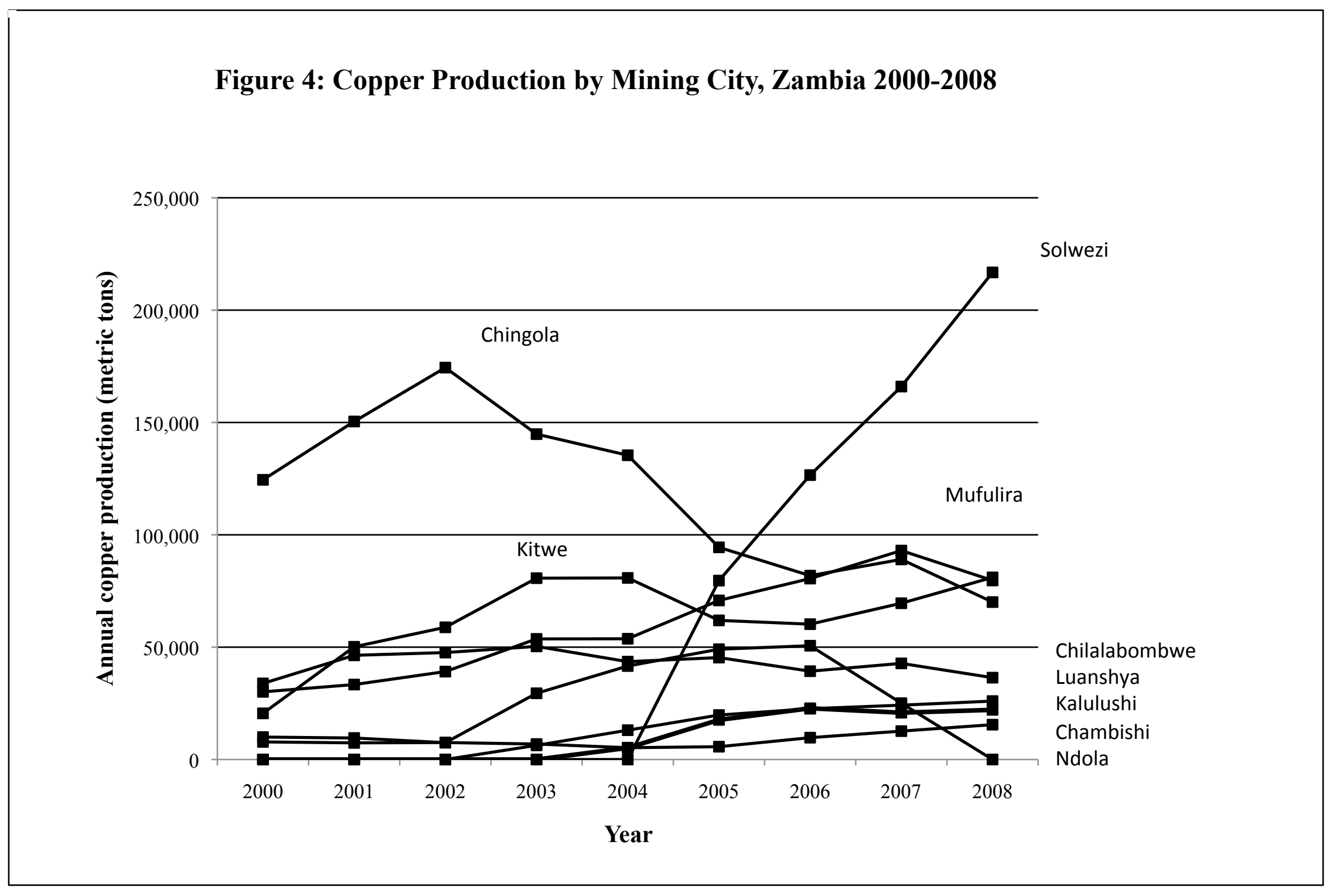


Figure 5: Employment at Copper Mines, Zambia 1999-2008

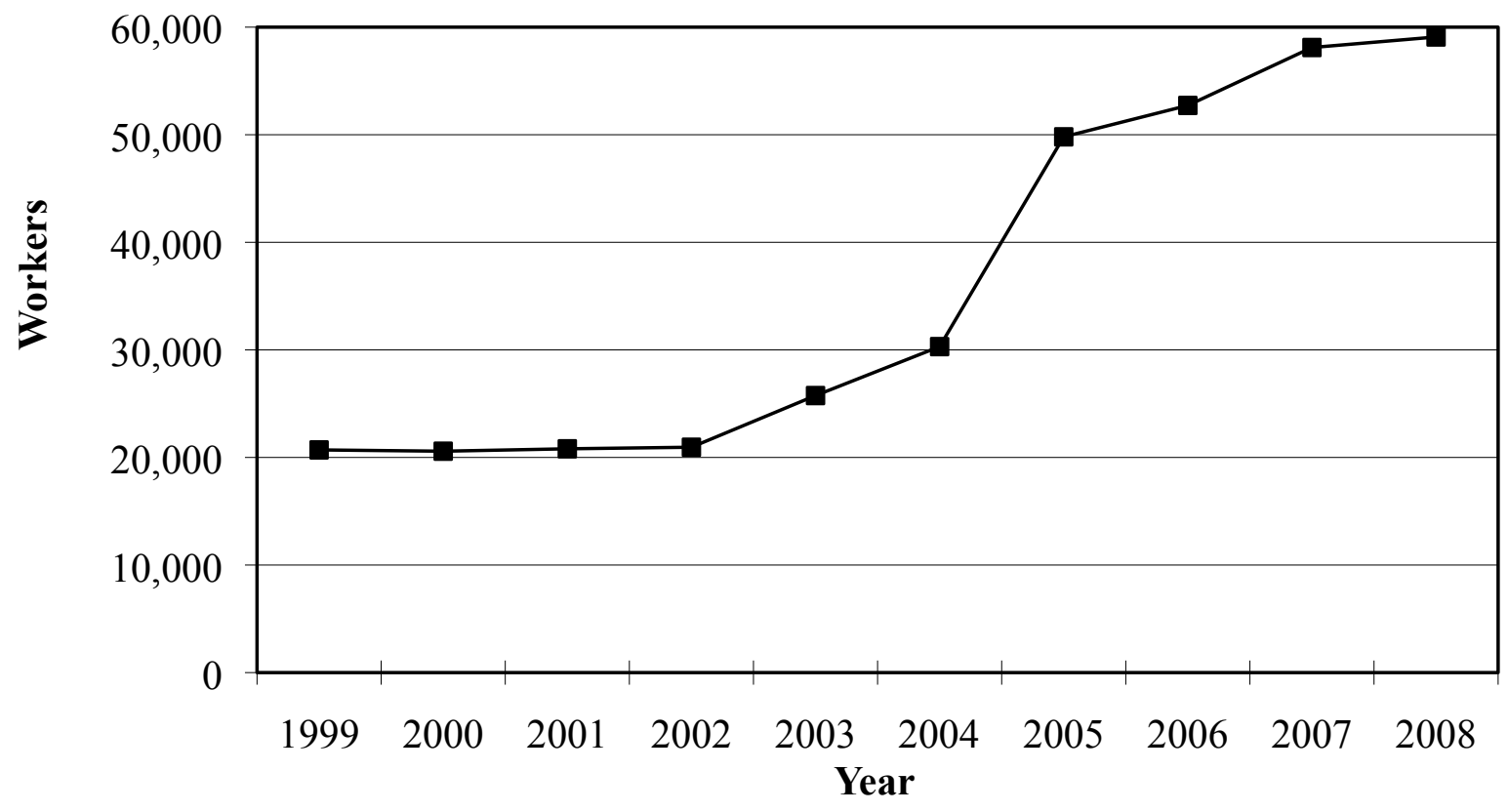


Table 1: Mean Sexual Behavior by Age and Gender of DHS and ZSBS Respondents

\begin{tabular}{|c|c|c|c|c|c|c|c|c|}
\hline Sexual behavior: & $\frac{\text { money }}{(1)}$ & $\begin{array}{c}\begin{array}{c}\text { multiple } \\
\text { partners }\end{array} \\
(2)\end{array}$ & $\begin{array}{c}\begin{array}{c}\text { proportion } \\
\text { unprotected }\end{array} \\
(3) \\
\end{array}$ & $\frac{\text { alcohol }}{(4)}$ & $\begin{array}{c}\begin{array}{c}\text { any } \\
\text { partner }\end{array} \\
(5) \\
\end{array}$ & $\begin{array}{c}\begin{array}{c}\text { sex in } \\
\text { past month }\end{array} \\
(6)\end{array}$ & $\frac{\text { pregnant }}{(7)}$ & $\frac{\text { married }}{(8)}$ \\
\hline \multicolumn{9}{|l|}{$\begin{array}{c}\text { Panel A: Females } \\
\text { Age }\end{array}$} \\
\hline $15-19$ & 0.052 & 0.021 & 0.79 & 0.04 & 0.42 & 0.42 & 0.22 & 0.20 \\
\hline $20-24$ & 0.034 & 0.020 & 0.85 & 0.10 & 0.81 & 0.61 & 0.42 & 0.65 \\
\hline $25-29$ & 0.022 & 0.020 & 0.88 & 0.14 & 0.88 & 0.66 & 0.44 & 0.76 \\
\hline $30-34$ & 0.020 & 0.014 & 0.91 & 0.14 & 0.88 & 0.66 & 0.39 & 0.77 \\
\hline $35-39$ & 0.014 & 0.010 & 0.93 & 0.13 & 0.83 & 0.64 & 0.30 & 0.78 \\
\hline $40-44$ & 0.014 & 0.016 & 0.93 & 0.13 & 0.78 & 0.60 & 0.15 & 0.73 \\
\hline $45-49$ & 0.007 & 0.008 & 0.96 & 0.11 & 0.74 & 0.59 & 0.04 & 0.72 \\
\hline $15-49$ & 0.028 & 0.017 & 0.88 & 0.11 & 0.74 & 0.61 & 0.32 & 0.61 \\
\hline
\end{tabular}

Panel B: Males

Age

\begin{tabular}{lllllllll}
$15-19$ & 0.066 & 0.059 & 0.64 & 0.02 & 0.32 & 0.31 & - & 0.01 \\
$20-24$ & 0.096 & 0.153 & 0.65 & 0.07 & 0.69 & 0.48 & - & 0.28 \\
$25-29$ & 0.074 & 0.201 & 0.75 & 0.13 & 0.90 & 0.67 & - & 0.70 \\
$30-34$ & 0.054 & 0.195 & 0.84 & 0.14 & 0.94 & 0.75 & - & 0.84 \\
$35-39$ & 0.046 & 0.193 & 0.85 & 0.14 & 0.94 & 0.75 & - & 0.88 \\
$40-44$ & 0.029 & 0.174 & 0.90 & 0.14 & 0.94 & 0.74 & - & 0.89 \\
$45-49$ & 0.025 & 0.166 & 0.93 & 0.12 & 0.94 & 0.79 & - & 0.91 \\
$50-54$ & 0.013 & 0.134 & 0.92 & 0.12 & 0.92 & 0.74 & - & 0.90 \\
$55-59$ & 0.020 & 0.115 & 0.95 & 0.11 & 0.91 & 0.74 & - & 0.90 \\
$15-59$ & 0.059 & 0.151 & 0.80 & 0.10 & 0.76 & 0.64 & - & 0.56 \\
\hline
\end{tabular}

Notes: Data come from 2001 and 2007 DHS and 2003 and 2005 ZSBS. Information on transactional sex in DHS available only for males. Information on alcohol consumption at sex not available in 2001 DHS. 
Table 2: Mean Characteristics of DHS and ZSBS Respondents by Location

\begin{tabular}{|c|c|c|c|}
\hline Sample: & $\frac{\text { mining cities }}{(1)}$ & $\frac{\text { rest of Zambia }}{(2)}$ & $\begin{array}{c}\begin{array}{c}\text { districts on copper } \\
\text { transportation routes }\end{array} \\
(3)\end{array}$ \\
\hline \multicolumn{4}{|l|}{ Consumer durables } \\
\hline Floor & 0.73 & 0.34 & 0.51 \\
\hline Refrigerator & 0.28 & 0.11 & 0.17 \\
\hline Television & 0.49 & 0.21 & 0.33 \\
\hline Radio & 0.66 & 0.56 & 0.62 \\
\hline Car & 0.05 & 0.03 & 0.04 \\
\hline Motorcycle & 0.00 & 0.00 & 0.01 \\
\hline Bicycle & 0.27 & 0.41 & 0.40 \\
\hline \multicolumn{4}{|l|}{ Demographic characteristics } \\
\hline In-migrant & 0.22 & 0.17 & 0.19 \\
\hline Female & 51.9 & 51.4 & 50.5 \\
\hline Age & 28.5 & 28.9 & 28.7 \\
\hline \multicolumn{4}{|l|}{ Sexual behavior } \\
\hline Money exchanged & 0.05 & 0.05 & 0.05 \\
\hline Multiple partners & 0.07 & 0.08 & 0.08 \\
\hline Proportion unprotected sex & 0.83 & 0.84 & 0.83 \\
\hline Alcohol use at sex & 0.17 & 0.09 & 0.11 \\
\hline Any partner & 0.69 & 0.76 & 0.73 \\
\hline Sex in past month & 0.56 & 0.63 & 0.63 \\
\hline Pregnant & 0.26 & 0.33 & 0.30 \\
\hline Married & 0.49 & 0.60 & 0.57 \\
\hline \multicolumn{4}{|l|}{ Health } \\
\hline HIV positive & 0.163 & 0.145 & 0.165 \\
\hline
\end{tabular}

Notes: Data come from 2001 and 2007 DHS and 2003 and 2005 ZSBS. Data on HIV status come from a single cross-section, the 2007 DHS. In-migrant is an indicator variable equal to one if the respondent had resided in the same household for less than twelve months at the time of the interview date. A mining city is defined as the area within a 10 kilometer radius of the approximate centroid of the urban area around each mining agglomeration. 


\section{Table 3: Pre-Boom Trends in Consumer Durables Ownership, Sexual Behavior, and Migration}

\begin{tabular}{|c|c|c|c|c|c|c|c|}
\hline \multicolumn{8}{|c|}{ Panel A: Consumer durables } \\
\hline Dependent variable: & floor & refrigerator & television & radio & car & motorcycle & bicycle \\
\hline & $(1)$ & $(2)$ & (3) & (4) & $(5)$ & $(6)$ & $(7)$ \\
\hline Time trend & $\begin{array}{c}-0.006 \\
(0.006)\end{array}$ & $\begin{array}{c}0.011 \\
(0.008)\end{array}$ & $\begin{array}{c}0.005 \\
(0.006)\end{array}$ & $\begin{array}{c}0.014 * * \\
(0.006)\end{array}$ & $\begin{array}{c}0.003 \\
(0.002)\end{array}$ & $\begin{array}{c}0.000 \\
(0.001)\end{array}$ & $\begin{array}{c}0.004 \\
(0.004)\end{array}$ \\
\hline Mining city $*$ time trend & $\begin{array}{c}0.003 \\
(0.004)\end{array}$ & $\begin{array}{l}-0.006 \\
(0.006)\end{array}$ & $\begin{array}{c}0.000 \\
(0.005)\end{array}$ & $\begin{array}{l}-0.004 \\
(0.002)\end{array}$ & $\begin{array}{c}0.002 \\
(0.004)\end{array}$ & $\begin{array}{l}0.000 \\
0.000\end{array}$ & $\begin{array}{c}-0.001 \\
(0.005)\end{array}$ \\
\hline Observations & 3,322 & 3,339 & 3,339 & 3,340 & 3,320 & 3,320 & 3,323 \\
\hline
\end{tabular}

\begin{tabular}{|c|c|c|c|c|c|c|c|c|c|}
\hline \multicolumn{10}{|c|}{ Panel B: Sexual behavior and migration } \\
\hline \multirow[t]{2}{*}{ Dependent variable: } & money & $\begin{array}{l}\text { multiple } \\
\text { partners }\end{array}$ & $\begin{array}{l}\text { proportion } \\
\text { unprotected }\end{array}$ & alcohol & $\begin{array}{c}\text { any } \\
\text { partner }\end{array}$ & $\begin{array}{c}\text { sex in } \\
\text { past month }\end{array}$ & pregnant & married & $\begin{array}{c}\text { resident less than } \\
\text { one year }\end{array}$ \\
\hline & $(1)$ & $(2)$ & $(3)$ & $(4)$ & $(5)$ & $(6)$ & $(7)$ & $(8)$ & $(9)$ \\
\hline Time trend & $\begin{array}{c}-0.013 * * * \\
(0.001)\end{array}$ & $\begin{array}{l}-0.001 \\
(0.002)\end{array}$ & $\begin{array}{c}0.011 * * * \\
(0.002)\end{array}$ & $\begin{array}{l}-0.011 \\
(0.029)\end{array}$ & $\begin{array}{c}-0.005^{* *} \\
(0.003)\end{array}$ & $\begin{array}{l}-0.006 \\
(0.004)\end{array}$ & $\begin{array}{c}0.010 * * * \\
(0.003)\end{array}$ & $\begin{array}{c}-0.008^{* *} \\
(0.003)\end{array}$ & $\begin{array}{c}-0.015^{* * *} \\
(0.002)\end{array}$ \\
\hline Mining city $*$ time trend & $\begin{array}{c}0.004 \\
(0.002)\end{array}$ & $\begin{array}{c}0.004 \\
(0.003)\end{array}$ & $\begin{array}{l}-0.002 \\
(0.002)\end{array}$ & $\begin{array}{c}0.047 \\
(0.035)\end{array}$ & $\begin{array}{c}0.005 * * \\
(0.002)\end{array}$ & $\begin{array}{c}0.001 \\
(0.003)\end{array}$ & $\begin{array}{c}0.003 \\
(0.002)\end{array}$ & $\begin{array}{c}0.001 \\
(0.002)\end{array}$ & $\begin{array}{l}-0.001 \\
(0.004)\end{array}$ \\
\hline Observations & 6,054 & 7,793 & 5,779 & 4,150 & 7,793 & 6,871 & 3,890 & 7,793 & 7,780 \\
\hline
\end{tabular}

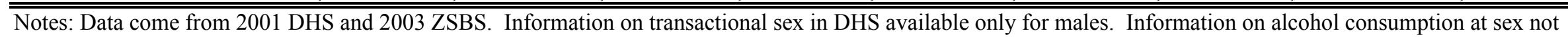

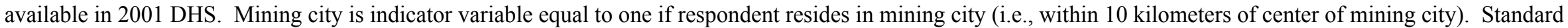
errors in parentheses clustered by district. All specifications include indicator variable equal to one if respondent resides in mining city. All specifications include month times year fixed effects and district fixed effects. In Panel B, all specifications include indicator variables for female and five-year age groups.

$* * *$ Significant at the $1 \%$ level, **Significant at $5 \%$ level, * Significant at $10 \%$ level. 
Table 4: Effect of Boom Copper Output on Household Consumer Durable Ownership

\begin{tabular}{|c|c|c|c|c|c|c|c|}
\hline Dependent variable: & $\begin{array}{c}\text { floor } \\
(1)\end{array}$ & $\begin{array}{c}\text { refrigerator } \\
(2)\end{array}$ & $\begin{array}{c}\text { television } \\
(3)\end{array}$ & $\begin{array}{c}\text { radio } \\
(4) \\
\end{array}$ & $\begin{array}{l}\text { car } \\
(5) \\
\end{array}$ & $\begin{array}{c}\text { motorcycle } \\
(6)\end{array}$ & $\begin{array}{c}\text { bicycle } \\
(7)\end{array}$ \\
\hline \multicolumn{8}{|c|}{ Panel A: Baseline specification } \\
\hline CU output, $0-10 \mathrm{~km}$ & $\begin{array}{c}0.204 \\
(0.132)\end{array}$ & $\begin{array}{c}0.192^{* *} \\
(0.089)\end{array}$ & $\begin{array}{c}0.240^{* *} \\
(0.107)\end{array}$ & $\begin{array}{c}0.061 \\
(0.067)\end{array}$ & $\begin{array}{c}0.030 * * * \\
(0.007)\end{array}$ & $\begin{array}{l}-0.003 \\
(0.002)\end{array}$ & $\begin{array}{c}0.005 \\
(0.070)\end{array}$ \\
\hline Observations & 11,417 & 11,439 & 11,446 & 11,462 & 11,433 & 11,434 & 11,440 \\
\hline \multicolumn{8}{|c|}{ Panel B: Linear trends } \\
\hline CU output, $0-10 \mathrm{~km}$ & $\begin{array}{c}0.345^{* *} \\
(0.133)\end{array}$ & $\begin{array}{c}0.249 * * \\
(0.118)\end{array}$ & $\begin{array}{c}0.321^{* *} \\
(0.131)\end{array}$ & $\begin{array}{c}0.178 * * * \\
(0.059)\end{array}$ & $\begin{array}{c}0.014 \\
(0.015)\end{array}$ & $\begin{array}{l}-0.004 * \\
(0.002)\end{array}$ & $\begin{array}{c}0.004 \\
(0.057)\end{array}$ \\
\hline Observations & 11,417 & 11,439 & 11,446 & 11,462 & 11,433 & 11,434 & 11,440 \\
\hline \multicolumn{8}{|c|}{ Panel C: Comparison group excludes districts on copper transportation routes } \\
\hline CU output, $0-10 \mathrm{~km}$ & $\begin{array}{c}0.202 \\
(0.132)\end{array}$ & $\begin{array}{c}0.203 * * \\
(0.095)\end{array}$ & $\begin{array}{c}0.255^{* *} \\
(0.106)\end{array}$ & $\begin{array}{c}0.078 \\
(0.071)\end{array}$ & $\begin{array}{c}0.031 * * * \\
(0.008)\end{array}$ & $\begin{array}{c}-0.002 \\
(0.002)\end{array}$ & $\begin{array}{c}0.015 \\
(0.052)\end{array}$ \\
\hline Observations & 7,289 & 7,301 & 7,304 & 7,317 & 7,298 & 7,299 & 7,303 \\
\hline \multicolumn{8}{|c|}{ Panel D: Value of output } \\
\hline $\mathrm{CU}$ value, $0-10 \mathrm{~km}$ & $\begin{array}{l}0.167^{*} \\
(0.087)\end{array}$ & $\begin{array}{l}0.184^{*} \\
(0.105)\end{array}$ & $\begin{array}{c}0.272 * * * \\
(0.103)\end{array}$ & $\begin{array}{c}0.061 \\
(0.065)\end{array}$ & $\begin{array}{c}0.049 * * * \\
(0.013)\end{array}$ & $\begin{array}{c}-0.002 \\
(0.003)\end{array}$ & $\begin{array}{c}0.001 \\
(0.087)\end{array}$ \\
\hline Observations & 11,417 & 11,439 & 11,446 & 11,462 & 11,433 & 11,434 & 11,440 \\
\hline
\end{tabular}

Notes: Data come from 2001 and 2007 DHS and 2003 and 2005 ZSBS. CU output, or boom-era copper output, is measured in '00,000s of metric tons. CU value, or value of boom-era copper output, is defined as metric tons of CU output times the LME spot price for copper (2005 US\$ '0,000s). Standard errors in parentheses clustered by district. All specifications control for whether respondent lives within 10 kilometers of center of mining city. All specifications include month times year fixed effects and district fixed effects. Panel B includes secular linear trend and linear trend for individuals residing within 10 kilometers of center of mining city.

$* * *$ Significant at the $1 \%$ level, ${ }^{* *}$ Significant at $5 \%$ level, $*$ Significant at $10 \%$ level. 
Table 5: Effect of Boom Copper Output on Sexual Behavior and Migration

\begin{tabular}{|c|c|c|c|c|c|c|c|c|c|}
\hline \multirow[t]{2}{*}{ Dependent variable: } & money & $\begin{array}{l}\text { multiple } \\
\text { partners } \\
\end{array}$ & $\begin{array}{c}\text { proportion } \\
\text { unprotected }\end{array}$ & alcohol & $\begin{array}{c}\text { any } \\
\text { partner }\end{array}$ & $\begin{array}{c}\text { sex in } \\
\text { past month }\end{array}$ & pregnant & married & $\begin{array}{c}\text { resident less than } \\
\text { one year }\end{array}$ \\
\hline & (1) & (2) & (3) & (4) & (5) & $(6)$ & (7) & $(8)$ & (9) \\
\hline \multicolumn{10}{|c|}{ Panel A: Baseline specification } \\
\hline CU output, $0-10 \mathrm{~km}$ & $\begin{array}{c}-0.046 * * \\
(0.020)\end{array}$ & $\begin{array}{c}-0.024 * * \\
(0.010)\end{array}$ & $\begin{array}{l}-0.006 \\
(0.041)\end{array}$ & $\begin{array}{l}-0.054^{*} \\
(0.032)\end{array}$ & $\begin{array}{l}-0.012 \\
(0.031)\end{array}$ & $\begin{array}{c}-0.061 * * * \\
(0.021)\end{array}$ & $\begin{array}{l}-0.058 \\
(0.044)\end{array}$ & $\begin{array}{l}-0.041 \\
(0.028)\end{array}$ & $\begin{array}{c}0.117 * * * \\
(0.035)\end{array}$ \\
\hline Observations & 16,296 & 25,181 & 18,660 & 21,538 & 25,181 & 21,844 & 12,968 & 25,181 & 25,145 \\
\hline \multicolumn{10}{|c|}{ Panel B: Linear trends } \\
\hline CU output, $0-10 \mathrm{~km}$ & $\begin{array}{c}-0.041 * * \\
(0.020)\end{array}$ & $\begin{array}{l}-0.029 \\
(0.020)\end{array}$ & $\begin{array}{l}-0.072 * \\
(0.041)\end{array}$ & $\begin{array}{c}-0.051 * * \\
(0.024)\end{array}$ & $\begin{array}{l}-0.041 \\
(0.039)\end{array}$ & $\begin{array}{c}-0.096 * * \\
(0.043)\end{array}$ & $\begin{array}{l}-0.100 * \\
(0.052)\end{array}$ & $\begin{array}{c}-0.082 * * * \\
(0.028)\end{array}$ & $\begin{array}{c}0.122 * * * \\
(0.031)\end{array}$ \\
\hline Observations & 16,296 & 25,181 & 18,660 & 21,538 & 25,181 & 21,844 & 12,968 & 25,181 & 25,145 \\
\hline \multicolumn{10}{|c|}{ Panel C: Comparison group excludes districts on copper transportation routes } \\
\hline CU output, $0-10 \mathrm{~km}$ & $\begin{array}{c}-0.045 * * \\
(0.018)\end{array}$ & $\begin{array}{c}-0.026 * * \\
(0.010)\end{array}$ & $\begin{array}{l}-0.011 \\
(0.042)\end{array}$ & $\begin{array}{l}-0.056^{*} \\
(0.032)\end{array}$ & $\begin{array}{l}-0.012 \\
(0.035)\end{array}$ & $\begin{array}{l}-0.047 * \\
(0.025)\end{array}$ & $\begin{array}{l}-0.073 \\
(0.045)\end{array}$ & $\begin{array}{l}-0.031 \\
(0.034)\end{array}$ & $\begin{array}{c}0.126 * * * \\
(0.035)\end{array}$ \\
\hline Observations & 9,832 & 15,529 & 11,701 & 13,285 & 15,529 & 13,657 & 8,093 & 15,529 & 15,504 \\
\hline \multicolumn{10}{|c|}{ Panel D: Value of output } \\
\hline CU value, $0-10 \mathrm{~km}$ & $\begin{array}{c}-0.082 * * * \\
(0.015)\end{array}$ & $\begin{array}{c}-0.056 * * * \\
(0.018)\end{array}$ & $\begin{array}{c}0.033 \\
(0.034)\end{array}$ & $\begin{array}{c}-0.096^{* *} \\
(0.041)\end{array}$ & $\begin{array}{l}-0.017 \\
(0.042)\end{array}$ & $\begin{array}{c}-0.085 * * \\
(0.040)\end{array}$ & $\begin{array}{l}-0.040 \\
(0.041)\end{array}$ & $\begin{array}{l}-0.057 \\
(0.040)\end{array}$ & $\begin{array}{c}0.180 * * * \\
(0.051)\end{array}$ \\
\hline Observations & 16,296 & 25,181 & 18,660 & 21,538 & 25,181 & 21,844 & 12,968 & 25,181 & 25,145 \\
\hline
\end{tabular}

Notes: Data come from 2001 and 2007 DHS and 2003 and 2005 ZSBS. Information on transactional sex in DHS available only for males. Information on alcohol consumption at sex not available in 2001 DHS. CU output, or boom-era copper output, measured in ' 00,000 s of metric tons. CU value, or value of boom-era copper output, defined as metric tonnes of CU output times LME spot price for copper (2005 US\$ '0,000s). Standard errors in parentheses clustered by district. All specifications include indicator variables for female and five-year age groups. All specifications control for whether respondent lives within 10 kilometers of center of mining city. All specifications include month times year fixed effects and district fixed effects. Panel B includes secular linear trend and linear trend for individuals residing within 10 kilometers of center of mining city.

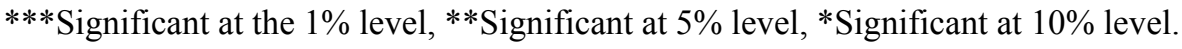




\section{Table 6: Heterogeneity by Gender in Effect of Boom Copper Output on Sexual Behavior and Migration}

\begin{tabular}{|c|c|c|c|c|c|c|c|c|c|}
\hline Dependent variable: & $\frac{\text { money }}{(1)}$ & $\begin{array}{c}\begin{array}{c}\text { multiple } \\
\text { partners }\end{array} \\
(2) \\
\end{array}$ & $\begin{array}{c}\text { proportion } \\
\text { unprotected } \\
(3) \\
\end{array}$ & $\frac{\text { alcohol }}{(4)}$ & $\begin{array}{c}\begin{array}{c}\text { any } \\
\text { partner }\end{array} \\
(5)\end{array}$ & $\begin{array}{c}\begin{array}{c}\text { sex in } \\
\text { past month }\end{array} \\
(6)\end{array}$ & $\frac{\text { pregnant }}{(7)}$ & $\frac{\text { married }}{(8)}$ & $\begin{array}{c}\text { resident less than } \\
\text { one year } \\
(9) \\
\end{array}$ \\
\hline CU output, $0-10 \mathrm{~km}$ & $\begin{array}{c}-0.048 * * * \\
(0.014)\end{array}$ & $\begin{array}{c}-0.028 \\
(0.020)\end{array}$ & $\begin{array}{l}-0.026 \\
(0.034)\end{array}$ & $\begin{array}{c}-0.131 * * * \\
(0.018)\end{array}$ & $\begin{array}{l}-0.023 \\
(0.050)\end{array}$ & $\begin{array}{c}-0.107 * * * \\
(0.025)\end{array}$ & $\begin{array}{l}-0.058 \\
(0.044)\end{array}$ & $\begin{array}{l}-0.042 \\
(0.035)\end{array}$ & $\begin{array}{c}0.136 * * * \\
(0.033)\end{array}$ \\
\hline Female*CU output, $0-10 \mathrm{~km}$ & $\begin{array}{c}0.023 \\
(0.040)\end{array}$ & $\begin{array}{c}0.004 \\
(0.041)\end{array}$ & $\begin{array}{c}0.039 * * \\
(0.016)\end{array}$ & $\begin{array}{c}0.144 * * \\
(0.055)\end{array}$ & $\begin{array}{c}0.022 \\
(0.059)\end{array}$ & $\begin{array}{c}0.089 * * * \\
(0.016)\end{array}$ & & $\begin{array}{c}0.002 \\
(0.038)\end{array}$ & $\begin{array}{l}-0.037 \\
(0.036)\end{array}$ \\
\hline Observations & 16,296 & 25,181 & 18,660 & 21,538 & 25,181 & 21,844 & 12,968 & 25,181 & 25,145 \\
\hline
\end{tabular}

Notes: Data come from 2001 and 2007 DHS and 2003 and 2005 ZSBS. Information on transactional sex in DHS available only for males. Information on alcohol consumption at sex not available in 2001 DHS. CU output, or boom-era copper output, is measured in '00,000s of metric tons. Standard errors in parentheses clustered by district. All specifications include indicator variables for female and five-year age groups. All specifications include controls for whether respondent resides within 10 kilometers of center of mining city and for interaction with female indicator variable. All specifications include month times year fixed effects and district fixed effects.

$* * *$ Significant at the $1 \%$ level, **Significant at $5 \%$ level, * Significant at $10 \%$ level. 
Table 7: Heterogeneity by Age in Effect of Boom Copper Output on Sexual Behavior and Migration

\begin{tabular}{|c|c|c|c|c|c|c|c|c|c|}
\hline Dependent variable: & $\frac{\text { money }}{(1)}$ & $\begin{array}{l}\begin{array}{l}\text { multiple } \\
\text { partners }\end{array} \\
(2) \\
\end{array}$ & $\begin{array}{c}\text { proportion } \\
\text { unprotected } \\
(3)\end{array}$ & $\frac{\text { alcohol }}{(4)}$ & $\begin{array}{c}\begin{array}{c}\text { any } \\
\text { partner }\end{array} \\
(5)\end{array}$ & $\begin{array}{c}\text { sex in } \\
\text { past month } \\
(6)\end{array}$ & $\frac{\text { pregnant }}{(7)}$ & $\frac{\text { married }}{(8)}$ & $\begin{array}{c}\text { resident less than } \\
\text { one year } \\
(9) \\
\end{array}$ \\
\hline CU output, $0-10 \mathrm{~km}$ & $\begin{array}{c}0.033 * * \\
(0.013)\end{array}$ & $\begin{array}{c}-0.078 * * * \\
(0.027)\end{array}$ & $\begin{array}{c}0.101 \\
(0.101)\end{array}$ & $\begin{array}{l}-0.010 \\
(0.014)\end{array}$ & $\begin{array}{c}0.063 \\
(0.115)\end{array}$ & $\begin{array}{c}-0.163 * * * \\
(0.058)\end{array}$ & $\begin{array}{c}-0.207^{* * *} \\
(0.048)\end{array}$ & $\begin{array}{l}-0.080 * \\
(0.046)\end{array}$ & $\begin{array}{l}0.110 * \\
(0.062)\end{array}$ \\
\hline Age $20-29 *$ CU output, $0-10 \mathrm{~km}$ & $\begin{array}{c}-0.176^{* * *} \\
(0.030)\end{array}$ & $\begin{array}{c}0.008 \\
(0.041)\end{array}$ & $\begin{array}{l}-0.130 \\
(0.134)\end{array}$ & $\begin{array}{c}-0.150 * * * \\
(0.022)\end{array}$ & $\begin{array}{c}-0.237 * * * \\
(0.041)\end{array}$ & $\begin{array}{l}-0.021 \\
(0.119)\end{array}$ & $\begin{array}{c}0.123 * * * \\
(0.028)\end{array}$ & $\begin{array}{l}-0.069 \\
(0.043)\end{array}$ & $\begin{array}{c}0.071 \\
(0.065)\end{array}$ \\
\hline Age $30-39 *$ CU output, $0-10 \mathrm{~km}$ & $\begin{array}{l}-0.053 \\
(0.036)\end{array}$ & $\begin{array}{c}0.127 * * * \\
(0.034)\end{array}$ & $\begin{array}{c}-0.288 * * * \\
(0.107)\end{array}$ & $\begin{array}{c}-0.124 * * * \\
(0.042)\end{array}$ & $\begin{array}{l}-0.081 \\
(0.141)\end{array}$ & $\begin{array}{c}0.142 * * \\
(0.069)\end{array}$ & $\begin{array}{c}0.227 * * * \\
(0.043)\end{array}$ & $\begin{array}{c}0.167 * * * \\
(0.029)\end{array}$ & $\begin{array}{c}0.002 \\
(0.083)\end{array}$ \\
\hline Age $40-49 *$ CU output, $0-10 \mathrm{~km}$ & $\begin{array}{l}-0.040 \\
(0.027)\end{array}$ & $\begin{array}{c}0.049 \\
(0.035)\end{array}$ & $\begin{array}{c}-0.317 * * * \\
(0.096)\end{array}$ & $\begin{array}{c}-0.172 * * * \\
(0.054)\end{array}$ & $\begin{array}{l}-0.083 \\
(0.133)\end{array}$ & $\begin{array}{c}0.032 \\
(0.078)\end{array}$ & $\begin{array}{c}0.046 * * \\
(0.021)\end{array}$ & $\begin{array}{l}-0.074 \\
(0.064)\end{array}$ & $\begin{array}{c}0.008 \\
(0.048)\end{array}$ \\
\hline Age $50-59 *$ CU output, $0-10 \mathrm{~km}$ & $\begin{array}{l}-0.033 \\
(0.028)\end{array}$ & $\begin{array}{l}0.049 * \\
(0.027)\end{array}$ & $\begin{array}{l}-0.172 \\
(0.133)\end{array}$ & $\begin{array}{l}-0.126 \\
(0.077)\end{array}$ & $\begin{array}{l}0.012 \\
(0.111)\end{array}$ & $\begin{array}{l}-0.028 \\
(0.084)\end{array}$ & & $\begin{array}{l}0.054 \\
(0.065)\end{array}$ & $\begin{array}{c}0.043 \\
(0.125)\end{array}$ \\
\hline Female * CU output, $0-10 \mathrm{~km}$ & $\begin{array}{l}-0.056 \\
(0.088)\end{array}$ & $\begin{array}{l}0.057 * \\
(0.032)\end{array}$ & $\begin{array}{l}-0.291 * \\
(0.173)\end{array}$ & $\begin{array}{l}-0.030 \\
(0.049)\end{array}$ & $\begin{array}{l}-0.096 \\
(0.067)\end{array}$ & $\begin{array}{c}0.036 \\
(0.125)\end{array}$ & & $\begin{array}{c}-0.076^{* * *} \\
(0.017)\end{array}$ & $\begin{array}{c}0.057 \\
(0.062)\end{array}$ \\
\hline Female * Age $20-29 *$ CU output, $0-10 \mathrm{~km}$ & $\begin{array}{c}0.149 * * \\
(0.060)\end{array}$ & $\begin{array}{l}-0.013 \\
(0.052)\end{array}$ & $\begin{array}{c}0.275 \\
(0.217)\end{array}$ & $\begin{array}{c}0.209 * * * \\
(0.032)\end{array}$ & $\begin{array}{c}0.214^{* * *} \\
(0.069)\end{array}$ & $\begin{array}{c}0.123 \\
(0.151)\end{array}$ & & $\begin{array}{c}0.134 * * * \\
(0.032)\end{array}$ & $\begin{array}{l}-0.165 \\
(0.114)\end{array}$ \\
\hline Female * Age $30-39 *$ CU output, $0-10 \mathrm{~km}$ & $\begin{array}{c}0.071 \\
(0.100)\end{array}$ & $\begin{array}{c}-0.166^{* * *} \\
(0.044)\end{array}$ & $\begin{array}{c}0.426 * * \\
(0.167)\end{array}$ & $\begin{array}{c}0.222 * * * \\
(0.046)\end{array}$ & $\begin{array}{c}0.110 \\
(0.085)\end{array}$ & $\begin{array}{c}0.015 \\
(0.136)\end{array}$ & & $\begin{array}{c}0.024 \\
(0.026)\end{array}$ & $\begin{array}{l}-0.068 \\
(0.113)\end{array}$ \\
\hline Female * Age $40-49 *$ CU output, $0-10 \mathrm{~km}$ & $\begin{array}{c}0.095 \\
(0.118)\end{array}$ & $\begin{array}{l}-0.048 \\
(0.030)\end{array}$ & $\begin{array}{c}0.546 * * * \\
(0.198)\end{array}$ & $\begin{array}{c}0.254 * * * \\
(0.064)\end{array}$ & $\begin{array}{c}0.096 \\
(0.064)\end{array}$ & $\begin{array}{l}-0.133 \\
(0.218)\end{array}$ & & $\begin{array}{c}0.063 \\
(0.100)\end{array}$ & $\begin{array}{l}-0.044 \\
(0.076)\end{array}$ \\
\hline Observations & 16,296 & 25,181 & 18,660 & 21,538 & 25,181 & 21,844 & 12,968 & 25,181 & 25,145 \\
\hline
\end{tabular}

Notes: Data come from 2001 and 2007 DHS and 2003 and 2005 ZSBS. Standard errors in parentheses clustered by district. All specifications include indicator variables for gender and five-year age groups, as well as month times year fixed effects and district fixed effects. All specifications control for whether respondent resides within 10 kilometers of center of mining city, as well as interaction of this indicator variable with age-group variables, female, and interactions thereof. Excluded age category is Age 15-19.

$* * *$ Significant at the $1 \%$ level, **Significant at $5 \%$ level, * Significant at $10 \%$ level. 
Table 8: Mean Characteristics of In-Migrants and Non-Migrants in Mining Areas

\begin{tabular}{|c|c|c|}
\hline & \multicolumn{2}{|c|}{ mining cities } \\
\hline & non-migrants & in-migrants \\
\hline & (1) & (2) \\
\hline \multicolumn{3}{|l|}{ Consumer durables } \\
\hline Floor & 0.77 & 0.80 \\
\hline Refrigerator & 0.32 & 0.35 \\
\hline Television & 0.56 & 0.60 \\
\hline Radio & 0.69 & 0.73 \\
\hline Car & 0.06 & 0.06 \\
\hline Motorcycle & 0.00 & 0.00 \\
\hline Bicycle & 0.31 & 0.22 \\
\hline \multicolumn{3}{|l|}{ Demographic characteristics } \\
\hline Female & 0.50 & 0.55 \\
\hline Age & 29.6 & 25.8 \\
\hline \multicolumn{3}{|l|}{ Sexual behavior } \\
\hline Money exchanged & 0.05 & 0.03 \\
\hline Multiple partners & 0.07 & 0.07 \\
\hline Proportion unprotected sex & 0.85 & 0.77 \\
\hline Alcohol use at sex & 0.17 & 0.15 \\
\hline Any partner & 0.69 & 0.68 \\
\hline Sex in past month & 0.57 & 0.48 \\
\hline Pregnant & 0.24 & 0.36 \\
\hline Married & 0.49 & 0.43 \\
\hline \multicolumn{3}{|l|}{ Health } \\
\hline HIV positive & 0.155 & 0.148 \\
\hline
\end{tabular}

Notes: Data come from 2001 and 2007 DHS and 2003 and 2005 ZSBS. Information on transactional sex in DHS available only for males. Information on alcohol consumption at sex not available in 2001 DHS.

Information on HIV status from 2007 DHS. Sample limited to respondents residing in copper mining cities (i.e., within 10 kilometers of center of one of copper mining cities identified in Section 2). In-migrant sample further limited to respondents from 2005 ZSBS or 2007 DHS. Non-migrants defined as respondents residing in same household for at least 5 years. In-migrants defined as respondents residing in same household for less than 12 months. 
Table 9: Heterogeneity by Migration Status in Effect of Boom Copper Output

\begin{tabular}{|c|c|c|c|c|c|c|c|c|}
\hline \multicolumn{9}{|l|}{ Panel A: Consumer durables } \\
\hline Dependent variable: & floor & refrigerator & television & radio & car & motorcycle & bicycle & \\
\hline & $(1)$ & $(2)$ & (3) & $(4)$ & $(5)$ & $(6)$ & $(7)$ & \\
\hline CU output, $0-10 \mathrm{~km}$ & $\begin{array}{c}0.210 \\
(0.139)\end{array}$ & $\begin{array}{c}0.195 * * \\
(0.095)\end{array}$ & $\begin{array}{c}0.234 * * \\
(0.105)\end{array}$ & $\begin{array}{c}0.034 \\
(0.070)\end{array}$ & $\begin{array}{c}0.045^{* * *} \\
(0.011)\end{array}$ & $\begin{array}{l}-0.003 \\
(0.002)\end{array}$ & $\begin{array}{c}0.030 \\
(0.071)\end{array}$ & \\
\hline In-migrant $* \mathrm{CU}$ output, $0-10 \mathrm{~km}$ & $\begin{array}{l}-0.035 \\
(0.060)\end{array}$ & $\begin{array}{l}-0.007 \\
(0.028)\end{array}$ & $\begin{array}{c}0.036 \\
(0.027)\end{array}$ & $\begin{array}{c}0.089 * * * \\
(0.024)\end{array}$ & $\begin{array}{c}-0.050 * * \\
(0.022)\end{array}$ & $\begin{array}{c}0.001 \\
(0.001)\end{array}$ & $\begin{array}{l}-0.069 * \\
(0.037)\end{array}$ & \\
\hline Observations & 11,395 & 11,417 & 11,424 & 11,440 & 11,411 & 11,412 & 11,418 & \\
\hline \multicolumn{9}{|l|}{ Panel B: Sexual behavior } \\
\hline Dependent variable: & $\frac{\text { money }}{(1)}$ & $\begin{array}{c}\begin{array}{c}\text { multiple } \\
\text { partners }\end{array} \\
(2)\end{array}$ & $\begin{array}{c}\text { proportion } \\
\text { unprotected }\end{array}$ & $\frac{\text { alcohol }}{(4)}$ & $\begin{array}{c}\begin{array}{c}\text { any } \\
\text { partner }\end{array} \\
(5)\end{array}$ & $\begin{array}{c}\text { sex in } \\
\text { past month } \\
(6)\end{array}$ & $\frac{\text { pregnant }}{(7)}$ & $\frac{\text { married }}{(8)}$ \\
\hline CU output, $0-10 \mathrm{~km}$ & $\begin{array}{c}-0.046 * * * \\
(0.017)\end{array}$ & $\begin{array}{l}-0.042 * \\
(0.022)\end{array}$ & $\begin{array}{l}-0.039 \\
(0.075)\end{array}$ & $\begin{array}{l}-0.043 \\
(0.032)\end{array}$ & $\begin{array}{l}-0.070 \\
(0.080)\end{array}$ & $\begin{array}{c}-0.146^{* *} \\
(0.071)\end{array}$ & $\begin{array}{c}-0.134 * * \\
(0.054)\end{array}$ & $\begin{array}{c}-0.103 * * \\
(0.047)\end{array}$ \\
\hline Age $30-59 *$ CU output, $0-10 \mathrm{~km}$ & $\begin{array}{c}0.047 * * * \\
(0.013)\end{array}$ & $\begin{array}{c}0.041^{* * * *} \\
(0.009)\end{array}$ & $\begin{array}{l}-0.069 \\
(0.051)\end{array}$ & $\begin{array}{c}0.029 \\
(0.031)\end{array}$ & $\begin{array}{c}0.123 \\
(0.112)\end{array}$ & $\begin{array}{c}0.091 \\
(0.094)\end{array}$ & $\begin{array}{c}0.100 * * \\
(0.041)\end{array}$ & $\begin{array}{c}0.109 * * \\
(0.054)\end{array}$ \\
\hline In-migrant $*$ CU output, $0-10 \mathrm{~km}$ & $\begin{array}{l}-0.047 \\
(0.029)\end{array}$ & $\begin{array}{l}-0.008 \\
(0.014)\end{array}$ & $\begin{array}{l}-0.004 \\
(0.073)\end{array}$ & $\begin{array}{l}-0.011 \\
(0.040)\end{array}$ & $\begin{array}{c}0.026 \\
(0.052)\end{array}$ & $\begin{array}{l}0.086^{*} \\
(0.048)\end{array}$ & $\begin{array}{l}-0.003 \\
(0.050)\end{array}$ & $\begin{array}{l}-0.038 \\
(0.050)\end{array}$ \\
\hline In-migrant $*$ Age $30-59 *$ CU output, $0-10 \mathrm{~km}$ & $\begin{array}{c}0.003 \\
(0.021)\end{array}$ & $\begin{array}{l}-0.014 \\
(0.034)\end{array}$ & $\begin{array}{l}-0.011 \\
(0.097)\end{array}$ & $\begin{array}{c}-0.149 * * \\
(0.058)\end{array}$ & $\begin{array}{c}-0.286 * * * \\
(0.089)\end{array}$ & $\begin{array}{c}-0.128 * \\
(0.075)\end{array}$ & $\begin{array}{l}-0.009 \\
(0.072)\end{array}$ & $\begin{array}{l}-0.073 \\
(0.062)\end{array}$ \\
\hline Observations & 16,267 & 25,145 & 18,637 & $\underline{21,507}$ & 25,145 & $\underline{21,814}$ & 12,947 & 25,145 \\
\hline
\end{tabular}

Notes: Data come from 2001 and 2007 DHS and 2003 and 2005 ZSBS. In-migrant is indicator variable equal to one if respondent resided in same household for less than 12 months. Standard errors in parentheses clustered by district. All specifications control for whether respondent resides within 10 kilometers of center of mining city, for whether respondent is in-migrant, and interaction thereof. Panel B includes interactions of these variables with Age 30-59 indicator variable; they also include controls for female and five-year age group. Excluded age category is Age 15-29. All specifications include month times year fixed effects and district fixed effects.

$* * *$ Significant at the $1 \%$ level, **Significant at $5 \%$ level, $*$ Significant at $10 \%$ level. 